\title{
Chikungunya and Zika Viruses: Co-Circulation and the Interplay between Viral Proteins and Host Factors
}

\author{
Sineewanlaya Wichit ${ }^{1,2, *}$, Nuttamonpat Gumpangseth ${ }^{1}$, Rodolphe Hamel $^{3}{ }^{\mathbb{D}}$, Sakda Yainoy ${ }^{1}$, Siwaret Arikit ${ }^{4}$, \\ Chuchard Punsawad ${ }^{2}$ (i) and Dorothée Missé ${ }^{3}$ (1) \\ 1 Department of Clinical Microbiology and Applied Technology, Faculty of Medical Technology, \\ Mahidol University, Nakhon Pathom 73170, Thailand; nuttamon.gump@gmail.com (N.G.); \\ sakda.yai@mahidol.ac.th (S.Y.) \\ 2 School of Medicine, Walailak University, Nakhon Si Thammarat 80160, Thailand; chuchard.pu@wu.ac.th \\ 3 MIVEGEC, Univ. Montpellier, CNRS, IRD, Montpellier, France; rodolphe.hamel@ird.fr (R.H.); \\ dorothee.misse@ird.fr (D.M.) \\ 4 Department of Agronomy, Faculty of Agriculture at Kamphaeng Saen, Kasetsart University Kamphaeng Saen \\ Campus, Nakhon Pathom 73140, Thailand; siwaret.a@ku.th \\ * Correspondence: sineewanlaya.wic@mahidol.ac.th; Tel.: +66-92-705-9933
}

check for updates

Citation: Wichit, S.;

Gumpangseth, N.; Hamel, R.; Yainoy, S.; Arikit, S.; Punsawad, C.; Missé, D. Chikungunya and Zika Viruses: Co-Circulation and the Interplay between Viral Proteins and Host Factors. Pathogens 2021, 10, 448. https: / / doi.org/10.3390/ pathogens 10040448

Academic Editor:

Luis Martinez-Sobrido

Received: 27 February 2021

Accepted: 6 April 2021

Published: 9 April 2021

Publisher's Note: MDPI stays neutral with regard to jurisdictional claims in published maps and institutional affiliations.

Copyright: (c) 2021 by the authors. Licensee MDPI, Basel, Switzerland. This article is an open access article distributed under the terms and conditions of the Creative Commons Attribution (CC BY) license (https:/ / creativecommons.org/licenses/by/ $4.0 /)$.

\begin{abstract}
Chikungunya and Zika viruses, both transmitted by mosquito vectors, have globally re-emerged over for the last 60 years and resulted in crucial social and economic concerns. Presently, there is no specific antiviral agent or vaccine against these debilitating viruses. Understanding viralhost interactions is needed to develop targeted therapeutics. However, there is presently limited information in this area. In this review, we start with the updated virology and replication cycle of each virus. Transmission by similar mosquito vectors, frequent co-circulation, and occurrence of co-infection are summarized. Finally, the targeted host proteins/factors used by the viruses are discussed. There is an urgent need to better understand the virus-host interactions that will facilitate antiviral drug development and thus reduce the global burden of infections caused by arboviruses.
\end{abstract}

Keywords: Chikungunya virus; Zika virus; antiviral; arbovirus; arbovirus-host interactions

\section{Introduction}

Chikungunya virus (CHIKV) and Zika virus (ZIKV) are arboviruses that have globally re-emerged and increased the global burden for public health. The viruses are mainly transmitted by the same mosquito vectors: Aedes aegypti and Ae. albopictus. However, ZIKV can also be transmitted by blood transfusion and sexual intercourse [1]. Arbovirus infections occur when mosquitoes blood-feed via human skin. During the meals, the mosquito inserts its mouthpiece into the skin and transmits infectious viral particles into both the epidermis and dermis, where inhabitant and migratory cells confront them [2]. People infected by CHIKV usually (up to 90\%) develop clinical symptoms characterized by headache, high fever, maculopapular rash, myalgia, arthralgia, and severe asthenia that might last for months or years [3]. In contrast, only 20-25\% of ZIKV-infected patients manifest symptoms, usually a "dengue-like" syndrome with a wide range of symptoms (headaches, fever, maculopapular rashes, arthralgia, conjunctivitis, and swelling at the extremities). However, of concern in ZIKV-infected patients are increasing reports of neurological complications (Guillain-Barré syndrome) and neurological birth defects (microcephaly) [4]. Despite the known healthcare threats caused by these viruses, there is still a lack of specific vaccines and therapeutics [5,6]. Normally, patients infected by CHIKV and ZIKV are given anesthetics, anti-inflammatory medications, and supportive care for relieving symptoms.

Antiviral drugs tend to use one of two main approaches, i.e., direct-acting antivirals (DAAs) and host-targeting antivirals (HTAs). DAAs directly target viral proteins and have proven to be successful. However, DAA compounds often display narrow-spectrum 
activity, and their development is time-consuming and costly [7]. HTAs are a promising approach that target host factors hijacked by viruses. This strategy demonstrates broad-spectrum activity and is developd using either newly discovered compounds or repurposing existing drugs [8]. Nevertheless, further knowledge of the virology, replication cycles, and host/virus interaction processes of these viruses is needed to help speed antiviral discovery. Therefore, this review article aims to provide updated research information in these areas, with a special focus on CHIKV and ZIKV infections. We hope the review will support further research by identifying new targets for potential therapeutics.

\section{Virology and Replication Cycle}

\subsection{Chikungunya Virus}

The arthropod-borne CHIKV is a member of Togaviridae family and Alphavirus genus. There are major four lineages: Asian, Indian Ocean, West African and East, and Central and South African (ECSA) [9]. Its viral particle is $70 \mathrm{~nm}$ in diameter and consists of an icosahedral nucleocapsid encapsulated by a lipid envelope. Inside the nucleocapsid, there is a 12-kilobase $(\mathrm{kb})$ positive-sense single-stranded RNA genome. The genomic RNA comprises two open reading frames (ORFs) that are translated into two polyproteins. There is an internal non-coding region, a $5^{\prime}$ untranslated region (UTR) with a type 0 cap, and a 3' UTR with a poly(A) tail, between the two ORFs (as shown in the lower-left corner of Figure 1) [10-12]. The ORF on the 5' side of the viral genome encodes the nonstructural polyprotein that contains non-structural protein 1 (nsP1; 535 aa), nsP2 (798 aa), nsP3 (530 aa), and nsP4 (611 aa). The 3' ORF produces the structural polyprotein that is further processed into capsid (C) (261 aa), envelop (E) 3 (64 aa), E2 (423 aa), 6K/TF (61 aa), and E1 (439 aa) proteins $[11,13,14]$.

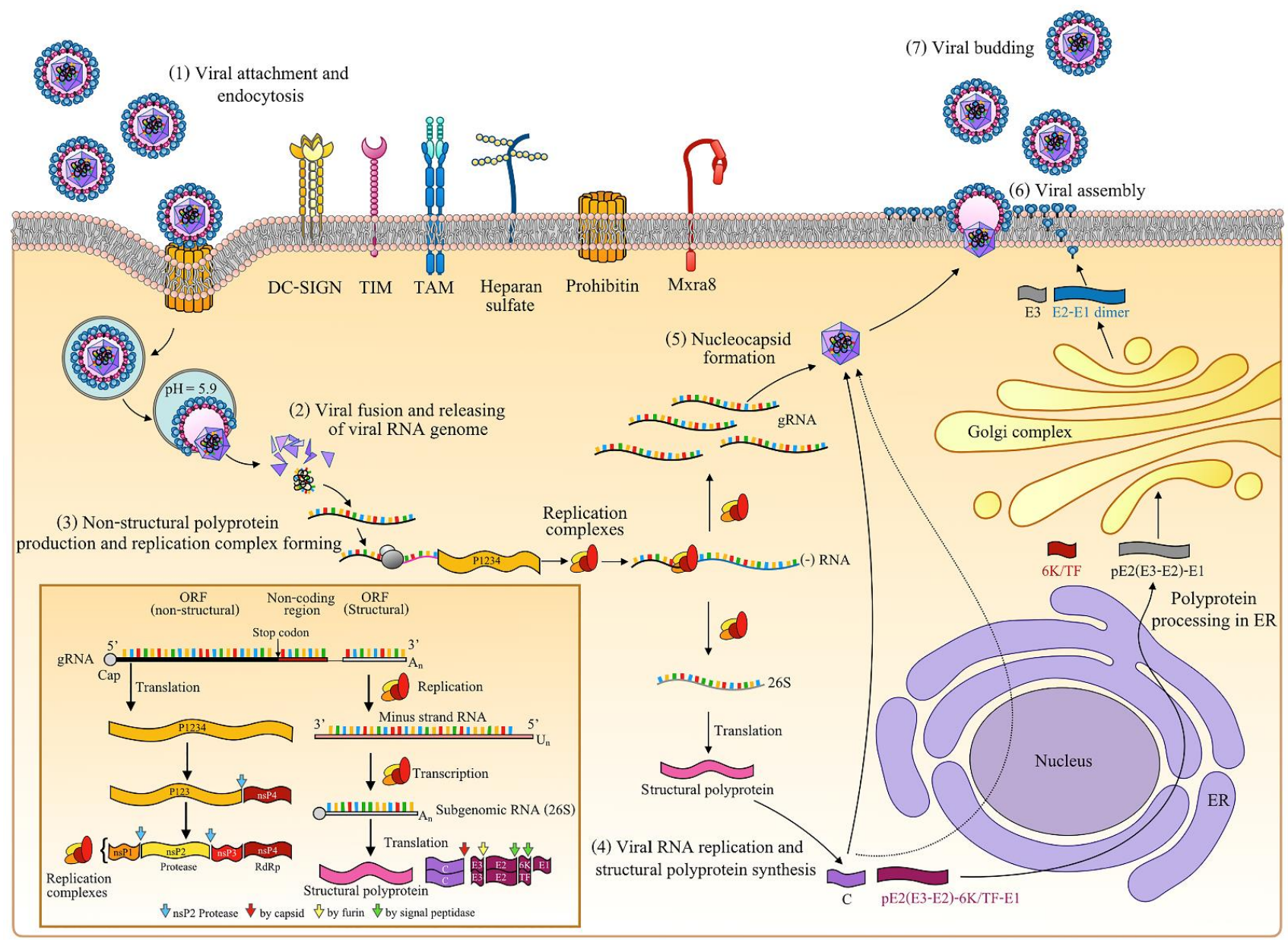

Figure 1. Replication cycle of Chikungunya virus. 
The structural proteins of CHIKV are involved in the viral entry, assembly, and budding steps of the viral replication cycle. The structural $C$ protein, comprised of two distinct domains (protease domain (C-terminal) and RNA binding domain (N-terminal) [15]), is used to form an icosahedral nucleocapsid that is covered by the envelope. Moreover, the CHIKV C protein contains the nuclear localization and exportation signals (NLS and NES, respectively), which are associated with protein transportation between nucleus and cytoplasm, a process which may be important for viral replication [16]. The CHIKV envelop protein is a host-derived plasma membrane with trimeric spikes, a trimer of glycoprotein E2, and an E1 heterodimer [17]. Both E2 and E1 predominantly contain $\beta$-sheet secondary structures, and each have three domains, which are the $\mathrm{C}, \mathrm{A}$, and $\mathrm{B}$ domains in E2 and the III, I, and II domains in E1 [10]. While the function of E1 glycoproteins is to mediate the virus-host cell membrane fusion, E2 facilitates the binding of virus and host-cell attachment factors [18]. The heterodimer of E2 and E1 is stabilized by the E3 protein, and it involves the translocation of viral structural polyproteins to the endoplasmic reticulum (ER). E2 and E3 are produced by the cleavage of the E2 precursor (pE2) by furin protease $[10,17,19]$, a small hydrophobic protein $6 \mathrm{~K} / \mathrm{TF}$ that is involved in membrane permeabilization and viral budding $[20,21]$.

The CHIKV non-structural protein (nsP1) expresses enzymatic activities (guanineN7-methyltransferase and guanylyltransferase) for 5' capping at the end of viral genome, a function necessary for viral RNA translation and the prevention of RNA degradation [22]. In addition, nsP1 helps to promote virion release by downregulating the expression of the virus restriction factor, tetherin [23]. On the nsP2 protein, the C-terminal contains a cysteine protease needed for non-structural polyprotein processing [24,25], while the $\mathrm{N}$-terminal is composed of a helicase and a nucleoside triphosphatase (NTPase) necessary for RNA unwinding and viral RNA capping [26,27].

$\mathrm{nsP3}$ is comprised of a macrodomain, an alphavirus unique domain (AUD), and a hypervariable domain (HVD) associated with a viral replication complex that promotes RNA replication and virulence [28-30]. The nsP4 functions as an RNA-dependent RNA polymerase (RdRp) essential for CHIKV RNA synthesis [31,32]. The non-structural polyprotein is first produced as nsP1234. Then, the polyprotein is cleaved into nsP123 and nsP4 by its protease, followed by further cleaving with the same protease to produce nsP1, $\mathrm{nsP2}$, and nsP3. Finally, nsP1, nsP2, nsP3, and nsP4 form a "replication complex" that is responsible for viral RNA synthesis (negative-stranded, positive-stranded, genomic, and sub-genomic) $[25,33]$.

The replication cycle of CHIKV is shown in Figure 1. CHIKV enters the host cell via clathrin-mediated endocytosis through the binding of its E2 protein with host attachment factors on the cell surface [34,35]. However, clathrin-independent endocytosis also has been reported [36]. The mammalian-cell attachment factors responsible for CHIKV binding include glycosaminoglycans (GAGs) (heparan sulfate, dextran sulfate, chondroitin sulfate, and dermatan sulfate [18]), dendritic-cell-specific ICAM-grabbing non-integrin (DC-SIGN) [37], TIM receptor family (T cell immunoglobulin mucin (TIM)-1), TAM (tyrosine protein kinase receptor 3 (Tyro3), Axl, and Mer) receptor family [38,39], prohibitin [40], and matrix remodeling-associated protein 8 (Mxra8) [41]. After internalization, the acidic environment in the endosome drives the fusion of the host cell endosomal membrane and viral E1 protein, resulting in the release of nucleocapsid and the subsequent release of the viral RNA genome into the cytoplasm [42].

The positive-sense single-stranded RNA genome is then translated into nsP1234 and further processed to form a viral replication complex. The complex then synthesizes viral negative-sense RNA, which serves as a template for positive-strand genomic (49S) and sub-genomic (26S) RNA synthesis [25,33]. The 26S sub-genomic RNA is translated into structural polyproteins (C-pE2(E3-E2)-6K/TF-E1). Later, the $C$ protein is released through the cleavage of its autoprotease in either the cytoplasm or nucleus, and the remaining pE2(E3-E2)-6K/TF-E1 polypeptide traffics to the ER for further processing [43]. Polypeptide cleaving occurs in the ER by host signal peptidase to form $\mathrm{pE} 2(\mathrm{E} 3-\mathrm{E} 2), 6 \mathrm{~K} / \mathrm{TF}$, and 
E1. The pE2(E3-E2) and E1 form a heterodimer before migrating to the Golgi complex. Furin protease in the Golgi complex drives the generation of mature E2 and E3, which subsequently dissociate to form an E2-E1 heterodimer during export from the Golgi complex to the plasma membrane $[10,17,19]$. The E2-E1 heterodimer arrives and embeds in the plasma membrane [17]. Finally, the nucleocapsid (built from oligomerization of the C protein covering viral genomic RNA) transports to host cell plasma membrane, where the nucleocapsid acquires an envelope before release as an assembled virus particle (mature virion) from the infected cell via the budding mechanism [44].

\subsection{Zika Virus}

The arbovirus, ZIKV, another global threat, is a member of the family Flaviviridae in the Flavivirus genus, which includes other human pathogenic viruses such as dengue virus (DENV), Japanese encephalitis virus (JEV), and West Nile virus (WNV) [45]. Two major lineages of ZIKV have been identified: African and Asian [46]. The mature virion is approximately $50 \mathrm{~nm}$ in diameter [47] and, as with other Flaviviruses, its structure is composed of an outer envelope enclosing an inner icosahedral nucleocapsid that contains a 10.8-kb positive single-stranded RNA [48]. Distinct from CHIKV, the ZIKV genome consists of a single ORF flanked by $3^{\prime}$ and 5' UTRs, and the end of the 5' UTR contains a viral promoter and a type I cap [49-51]. The ORF encodes a large single polyprotein that is processed into three structural proteins, $C$, pre-membrane (prM), and E, as well as the seven non-structural proteins NS1, NS2A, NS2B, NS3, NS4A, NS4B, and NS5 [50,52-54].

ZIKV structural proteins play an important role in the formation of infectious virions, receptor binding, viral assembly, and release. The envelope protein, which is prominent on the surface of virus particles, consists of four domains: a stem-transmembrane domain pair involved in membrane attachment and three $\beta$-sheet domains designated as ectodomains I, II, and III. Domain II is required for viral fusion, whereas domain III is needed for receptor binding $[55,56]$. Situated under the E protein, there is a membrane $(\mathrm{M})$ protein, a part of the prM protein processed by the host furin protease during virion maturation and adherent to the virion's host-derived lipid membrane. Inside the lipid membrane, icosahedral nucleocapsid constructed from structural C protein is encapsulated $[47,48]$. The viral $C$ protein is formed as a homodimer with two different parts on opposite sides: a hydrophobic side thought to bind with the viral membrane protein and a highly positively charged side theorized to contact with the viral RNA genome. Together, these suggest that $C$ protein strongly affects the viral assembly process [57].

ZIKV non-structural proteins are implicated in viral genome replication, particle assembly, and host immune evasion. The NS1 protein, a membrane-associated homodimer form, plays an important role in viral replication by forming a replication complex. Moreover, the NS1 protein is secreted from the infected cell as hexameric proteoliposomes that aid immune evasion through the alteration of the complement system [58-60] and reducing the type-I interferon (IFN) production at the TANK binding kinase 1 (TBK1) phosphorylation step [61]. ZIKV NS1 protein's structure is similar to that of NS1 of other flaviviruses. Therefore, it is difficult to differentiate this virus from other members of the family via NS1.

However, the ZIKV NS1 protein shows unique electrostatic potentials on bound host factors and protective antibodies [62]. NS2A, NS2B, NS4A, and NS4B are membraneassociated hydrophobic proteins located within ER membranes and are implicated in the viral replication complex. Moreover, the NS2A protein interacts with viral RNA and proteins to facilitate virion assembly $[63,64]$. It also acts as an innate immune response antagonist by blocking TBK1 phosphorylation and suppressing type-I IFN [61]. NS2B is a cofactor with NS3 to form a serine protease complex that is involved in viral polyprotein processing [65]. The ZIKV NS3 protein has two functional domains-protease and helicase - that exhibit multiple enzymatic activities such as serine protease [65], RNA helicase [66], and NTPase [67]. Therefore, it plays multiple roles in the virus replication cycle, e.g., the unwinding of double-stranded RNA during virus replication and polyprotein processing [66]. For NS4B, in addition to associating with the replication complex dur- 
ing viral replication, it also acts in immune evasion by blocking interferon signaling by targeting to TBK1 [61]. The NS5 protein also suppresses IFN signaling through the proteasomal degradation of human STAT2 [68]. The ZIKV NS5 protein has two domains-the $\mathrm{N}$-terminal methyltransferase (MTase) and C-terminal RNA-dependent RNA polymerase (RdRp) domains - that are essential for viral genome synthesis, genome stabilization, and, as mentioned earlier, host immune response evasion [69,70].

As shown in Figure 2, the ZIKV replicative cycle begins with the attachment of the viral $E$ proteins to specific attachment factors on the host cell surface. Several factors are responsible for ZIKV entry including DC-SIGN, TIM receptor family (TIM-1 and TIM-4), TAM receptor family (AXL and Tyro3) [71], and glucose-regulating protein 78 (GRP78) [56].

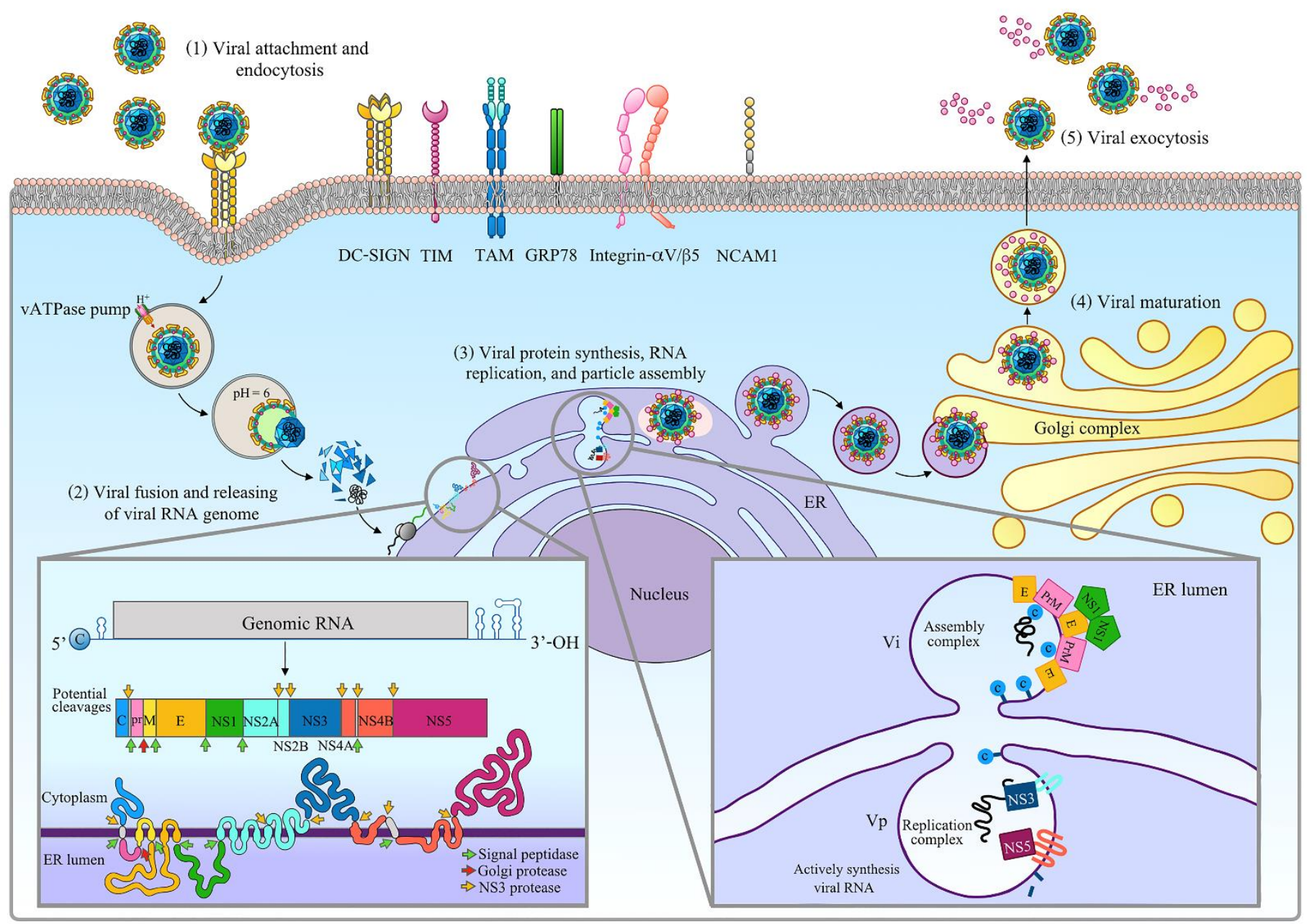

Figure 2. Replication cycle of Zika virus.

Recently, two attachment factors have been reported to mediate ZIKV infection: the integrin- $\alpha \mathrm{V} / \beta 5$, which facilitates viral infection of neuronal stem cells [72], and the neural cell adhesion molecule (NCAM1), which facilitates the infection of human astrocytoma cells [73]. After these interactions, the virus subsequently internalizes via clathrindependent or clathrin-independent endocytosis $[74,75]$. Then, a vacuolar ATPase pumps protons into the endosome to create an acidic environment that triggers fusion between viral envelope proteins and endosomal membranes. This is followed by the $C$ protein degradation of the viral nucleocapsid, resulting in the release of viral RNA into the cell cytoplasm [75]. In host cell cytosol, viral RNA translation occurs immediately after release and results in the generation of a polyprotein with an N-terminal ER localization signal. This polyprotein traffics to localize at the ER membrane, which comprises prM, E, NS1 and parts of NS2A, NS4A, and NS4B located inside the ER lumen, while C, NS3, and NS5 
face toward the cytoplasm. This polyprotein is cleaved by host proteases (cleaving ER lumen-facing parts) and a viral protease (cleaving cytosol-facing parts) to obtain virus structural and non-structural proteins [76]. Then, the replication complex forms and viral genome synthesis occurs. NS1, NS2A, NS2B, NS4A, and NS4B transmembrane proteins associate with modified lipids that provide a molecular scaffold for complex replication. The complex then induces ER membrane rearrangements that facilitate the generation of vesicle pockets (VPs) where the replication complex is located [77-79].

Viral RNA replication occurs through the replication complex in the VPs. The positive single-stranded RNA is transcribed using NS5 proteins (RdRp) to produce dsRNA which is comprised of both positive and negative strands. This dsRNA is unwound by the NS3 helicase to generate both positive and negative ssRNAs. The negative ssRNAs serve as templates for further transcription, while positive ssRNAs combine with prM, C, and E proteins in the ER to assemble immature virions. The immature particles subsequently traffic from ER to Golgi complex and the trans-Golgi network where the acidic environment reveals the prM cleavage site. Finally, the prM is cleaved by a host furin protease, thus allowing for particle maturation, followed by the release of mature virions from infected cells by exocytosis [80-82].

\section{Co-Circulation of Chikungunya and Zika Viruses}

\subsection{Geographic Distribution of Chikungunya and Zika Viruses}

CHIKV was first reported in southern Tanzania in 1952 [83], followed by occasional reports of CHIKV-infected cases in Africa [84-86] and Asia [87-90]. The first epidemic in Asia was documented in Bangkok, Thailand, in 1958 [88]. Since then, CHIKV has rapidly spread worldwide. An outbreak in Kenya in 2004, which subsequently caused infections in most islands of the Indian Ocean over the next two years [91-94]. CHIKV from the Indian Ocean spread to many countries in Asia such as India [95,96], Sri Lanka, Myanmar [97], and Thailand [98], as well as to northern Italy in 2007 (the first report in Europe) [99]. In 2010, the first autochthonous case was reported in Europe [100], and, in the same year, CHIKV was also reported in several countries in Asia [101-103]. In the Americas, the first autochthonous case was identified in Saint Martin in 2013 [104]. CHIKV subsequently caused viral infections through the North, Central, and South Americas [105,106]. As of 2021, 115 countries/territories have been affected by CHIKV (Figure 3).

ZIKV was first identified in 1947 from a sentinel rhesus monkey during a yellow fever project in the Zika forest near Entebbe in Uganda [107]. The first human cases were reported in 1952 from Uganda and the United Republic of Tanzania [108]. Since then, ZIKV-infected cases have occurred sporadically in Africa [109-114] and Asia [90,115-118]. A large outbreak of ZIKV occurred outside Africa and Asia in 2007 in the Pacific Ocean country of the Federated States of Micronesia (on "Yap Island"), thus causing infection of approximately $73 \%$ of residents [119].

In 2013-2014, ZIKV caused an outbreak in French Polynesia and was subsequently transmitted to other Pacific islands including Easter Island, New Caledonia, and the Cook Islands [120-123]. A year later, in 2015, the first outbreak of ZIKV in the Americas took place in Brazil and rapidly spread through many countries in the region [124,125]. As of 2021, 86 countries/territories worldwide report having ZIKV-infected cases (Figure 3). CHIKV and ZIKV co-circulate in more than 80 of these countries/territories (Figure 3).

\subsection{Cases of Chikungunya and Zika Virus Co-Infection}

CHIKV and ZIKV are arboviruses, meaning that they can be transmitted by bloodfeeding arthropods. For ZIKV, the main vector for transmission from human to human is Aedes mosquitoes [128-131]. CHIKV is mainly transmitted by Ae. aegypti. In 2006, a CHIKV E1 mutation $(\mathrm{A} 226 \mathrm{~V})$ resulted in increased viral replication in Ae. albopictus, and this mosquito species became another important vector of the virus [132-135]. As CHIKV and ZIKV co-circulate in multiple countries worldwide, there is a high likelihood of co-infection in a patient. Indeed, 142 cases of CHIKV and ZIKV co-infection have been reported from 
six countries (a country in Central America, two countries in North America, and three countries in South America).

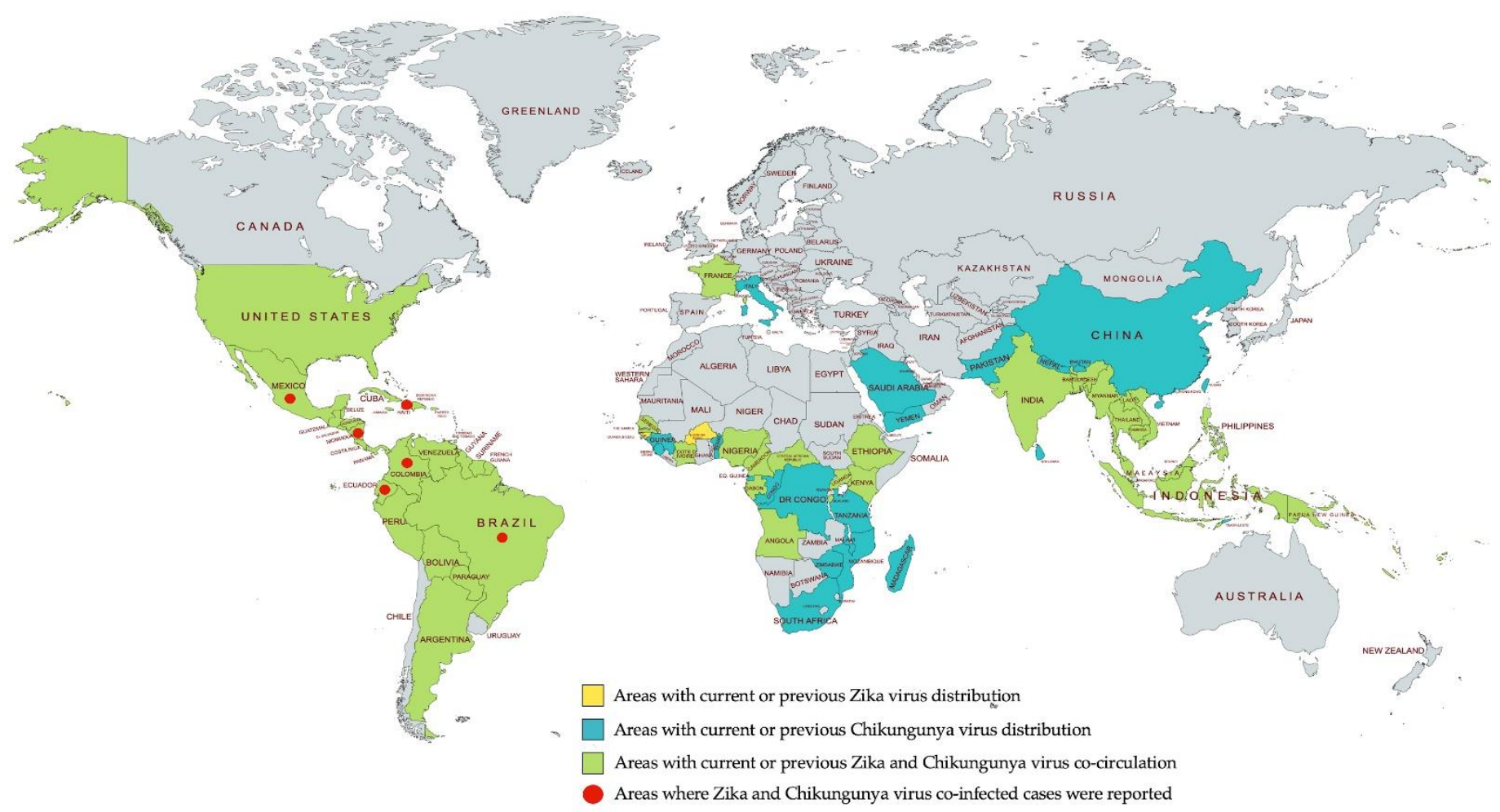

Figure 3. Geographic distribution of Chikungunya and Zika viruses. Information retrieved from the U.S. CDC website, last accessed in February 2021 [126,127]. Map was created with mapchart.net.

\subsubsection{Haiti}

From May 2014 to February 2015, during the CHIKV outbreak in the Americas, Jacob and team investigated schoolchildren with febrile illness to determine diagnosis, clinical characterization, and epidemiological features. In the same period, DENV and ZIKV were reported in the area $[125,136]$. Therefore, blood samples from children were tested for these viruses and identified six co-infections of CHIKV and ZIKV by quantitative reverse transcription polymerase chain reaction (qRT-PCR) [137].

\subsubsection{Colombia}

DENV has been endemic in Colombia for a long time [138], while CHIKV arrived in $2014[139,140]$ and was followed by ZIKV in 2015 [141], thus leading to the local cocirculation of these viruses. Between August 2015 and April 2016, blood samples obtained from patients with febrile illness at the Jorge Cristo Sahium Hospital were found positive for DENV, CHIKV, and ZIKV by conventional PCR, qRT-PCR, and genotypic sequencing. Eight patient samples were positive for both CHIKV and ZIKV, while three samples were positive for DENV, CHIKV, and ZIKV, indicating co-circulation and co-infection by the viruses in Colombia [142]. From the end of 2015 to December 2016, ZIKV-suspected samples from the National Surveillance System in Public Health (SIVIGLIA) were investigated by singleplex and multiplex qRT-PCR for DENV, CHIKV, and ZIKV. Twenty-eight CHIKV and ZIKV co-infected samples were found, and five of these co-infected cases were fatal [143].

In addition to these two cross-sectional studies, there were reports of autochthonous cases in 2016. A study reported co-infection in a 49-year-old male who traveled through the Sucre and Bolivar departments of Colombia. His blood sample was reported positive for DENV and ZIKV RNA genomes, as well as for CHIKV IgM antibodies [144]. In the same year and department, a 33-year-old pregnant woman was determined to be positive for DENV serotype 2, the CHIKV Asian genotype, and ZIKV Asian lineage by nested RT-PCR 
and sequencing, indicating co-infection with DENV, CHIKV, and ZIKV [145]. In 2018, a pregnant woman from the southern part of Colombia was found to have a co-infection of Toxoplasma gondii, CHIKV, and ZIKV using PCR assays of amniotic fluid. In this case, the pregnancy was medically terminated at 29 weeks of gestation [146].

Another 2016 report describes a 40-year-old woman living in Florida (no local transmission of CHIKV or DENV at that time) who traveled to Colombia for seven days. She became ill and was studied with tests that included qRT-PCR for arbovirus-she was found positive for ZIKV. Arthralgias persisted in the patient for months, and her sample was further evaluated by inoculating it into cell cultures. Using qRT-PCR, CHIKV and ZIKV were observed in the cultures, thus indicating co-infection by CHIKV and ZIKV in this patient. Viral genome sequencing was also performed, and the results showed a close relationship to the CHIKV and ZIKV strains previously isolated in Colombia [147]. This case was investigated in the United States after her return, and it warned of a high risk for CHIKV and ZIKV introduction into a new region of the world since transmission would be easy via one bite of a vector mosquito.

\subsubsection{Brazil}

After CHIKV was introduced into the Americas in 2013, it was reported to cause the first outbreak in Brazil in 2014 [148], while ZIKV was first reported in Brazil in 2015 [124,125], suggesting the co-circulation of CHIKV and ZIKV in that country. From May 2015 to 2016, Brazilian patients with illness suspected of arbovirus infection were investigated for CHIKV and ZIKV using qRT-PCR. The result showed two cases of co-infection with CHIKV and ZIKV [149]. These data indicated co-infection during virus co-circulation in Brazil, even in a decreasing period of ZIKV infection in which asymptomatic patients might still spread ZIKV. Therefore, detecting and monitoring co-infected cases is still important. In addition, during this co-circulation period, there were many reports of co-infected cases in Brazil. One study reported two cases of co-infection with CHIKV and ZIKV from the ECSA lineage of CHIKV and the Asia lineage of ZIKV [150]. Another study investigated samples from the University Hospital Clementino Fraga Filho/Federal University of Rio de Janeiro with qRT-PCR and reported one case of the CHIKV and ZIKV co-infection [151]. Because a ZIKV infection during the gestation period can cause central nervous system malformations in the fetus, pregnant women were studied from September 2015 through May 2016. Three co-infections of CHIKV and ZIKV in these women at the acute febrile illness clinic were detected by IgM antibodies and viral RNA [152].

During the same period, a study focused on differential diagnosis in patients with neurological disorders. A sample of patients who had developed a neurological complication associated with ZIKV was studied. Five cases of CHIKV and ZIKV, as well as one case of a DENV, CHIKV, and ZIKV co-infection, were detected using ELISA and qRT-PCR [153]. From March to May 2016, an investigation of samples from private hospitals using qRTPCR found 36 cases of co-infection by CHIKV and ZIKV. CHIKV-positive samples in this study were randomly chosen for further analysis by NGS and revealed the ECSA lineage of CHIKV [154].

In 2016, a 74-year-old male resident from Recife, northeast Brazil, was reported to have a co-infection by CHIKV and ZIKV with severe meningoencephalitis. The CSF and serum of the patient were tested for ZIKV and CHIKV using qRT-PCR and IgM serology, and they found ZIKV and CHIKV RNA in serum and IgM against CHIKV in CSF. However, there were no antibodies against ZIKV in either the CSF or serum [155]. Moreover, the first fatal pregnancy, a 20-year-old at 21 weeks of gestation, that was associated with CHIKV and ZIKV co-infection was reported. Her blood sample was positive for IgM and IgG specific for DENV and CHIKV, and it was IgG specific for ZIKV. Additionally, CHIKV RNA was detected by qRT-PCR. CHIKV and ZIKV RNA were detected in the placenta and kidney, respectively, of the dead fetus, associating the fetal death with the co-infection [156]. Recently, from the end of 2017 to early 2018, samples from several cities in Minas Gerais were tested by ELISA for antibodies against DENV, CHIKV, and ZIKV. The results showed 
five cases that were positive for IgM specific to CHIKV and ZIKV, and one case positive for IgM specific to all three viruses [157].

\subsubsection{Nicaragua}

The first CHIKV autochthonous case in Nicaragua was recorded in September 2014, whereas the first ZIKV case was identified in January 2016 [125,158,159]. During the epidemic of these two viruses, ten co-infected cases with CHIKV and ZIKV and four co-infected cases of DENV, CHIKV, and ZIKV were detected using a ZDC assay (a multiplex qRT-PCR for detecting ZIKV, DENV and CHIKV) [159]. Furthermore, between September 2015 and April 2016, serum samples collected from Ministry of Health facilities and tested using the same assay detected sixteen cases of CHIKV and ZIKV and six cases of DENV, CHIKV, and ZIKV co-infection [160].

\subsubsection{Ecuador}

DENV has been endemic in Ecuador since 1988 [161], while CHIKV was first identified in 2014 and continues to be epidemic [162]. ZIKV was introduced in January 2016 [163], and its outbreak might have driven the co-circulation and co-infection that year. A report of co-infection at the Hospital Luis Vernaza in Guayaquil was published with three cases that were diagnosed in early 2016. The first patient was a 43-year-old male, the second was a 43-year-old woman who lived in the United States and traveled to Ecuador for two weeks, and the last was a 57-year-old female with severe neurologic symptoms. All patients were found to be positive for DENV, CHIKV, and ZIKV RNA using a ZDC assay [164]. Furthermore, a total of four CHIKV and ZIKV co-infection cases and four DENV, CHIKV, and ZIKV co-infection cases were detected by a ZDC assay on CSF samples from the Hospital Luis Vernaza in Guayaquil in 2016 [165].

\subsubsection{Mexico}

In Mexico, dengue virus re-emerged in 1978 after being absent since 1961 [166], while the first cases of CHIKV and ZIKV were reported in 2014 and 2015, respectively $[167,168]$. These three arboviruses are considered endemic in this country and co-circulate in the same areas. However, dengue-infected cases were detected in 2018, and outbreaks occurred in several states in 2019. CHIKV and ZIKV seemed to decrease in circulation these two years, but they were still present $[125,136,169]$.

During a DENV outbreak February to August 2019, blood samples from pregnant women who lived in the central region of the state of Chiapas were collected and found positive for DENV, CHIKV, and ZIKV using qRT-PCR. Cases of co-infection with CHIKVZIKV and DENV-CHIKV-ZIKV were found [170].

\section{Interplay of Virus Proteins and Host Factors}

To develop antiviral agents, a greater understanding of virus-host interaction is required. Summaries of the viral protein-host factor interactions of CHIKV and ZIKV are shown in Tables 1 and 2, respectively.

\subsection{Cellular Entry and Targets}

CHIKV and ZIKV are enveloped arboviruses which come from different families. However, these viruses display similar components: envelope, membrane, and icosahedral nucleocapsid around a viral RNA genome. Binding to and entering human host cells begin with binding between viral proteins and host cell attachment factors. The envelope protein E2 of CHIKV and E protein of ZIKV have been documented to be the viral proteins involved in this task $[18,71]$. Interestingly, among the host cell attachment factors, three identical factors have been reported: DC-SIGN, hTIM-1, and TAM [37-39,71] (Figure 4). 


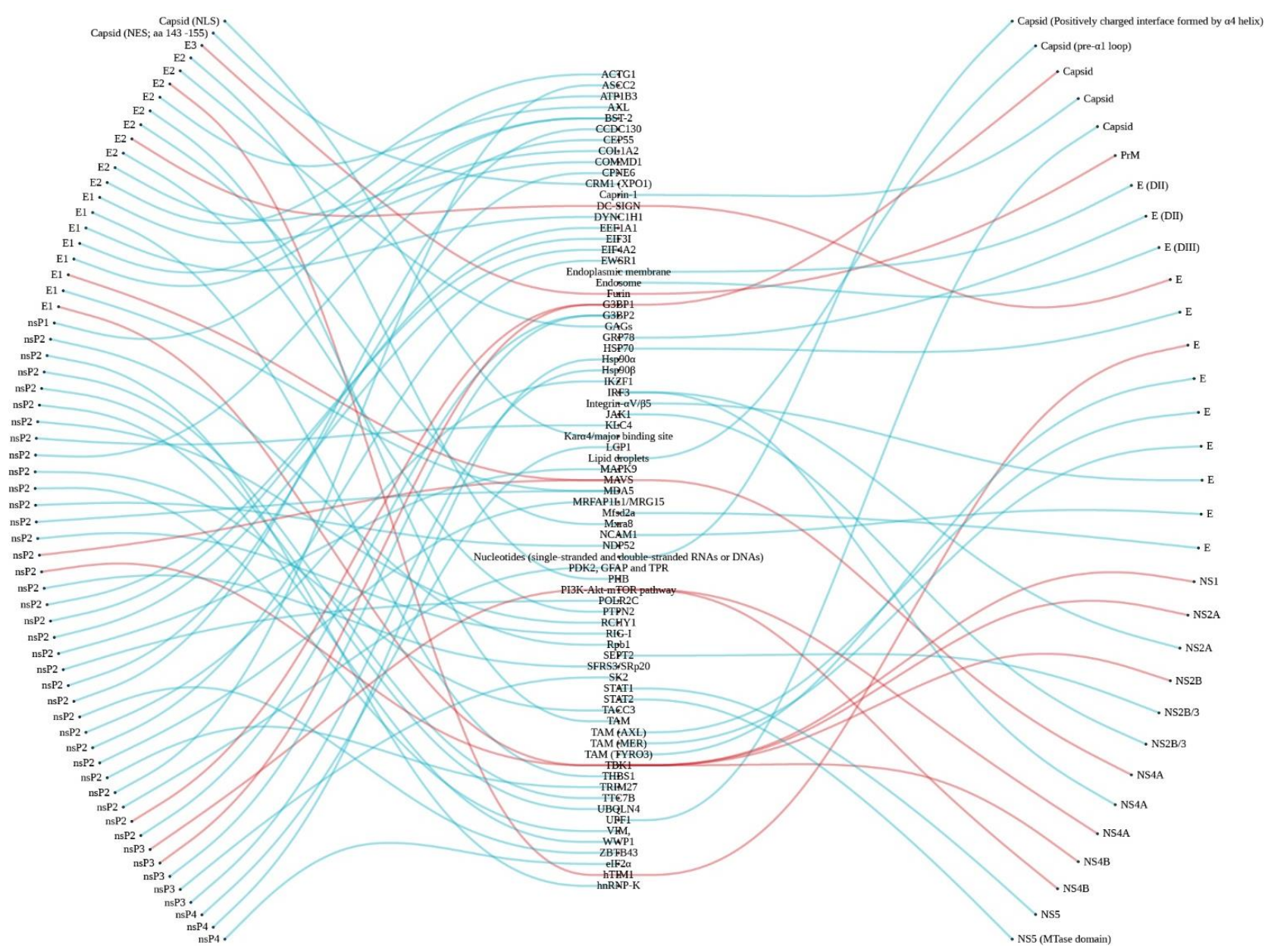

Figure 4. Eye diagram linking host factors (middle) with Chikungunya virus proteins (left) and Zika virus proteins (right). Red lines represent human proteins that can interact with both Chikungunya and Zika virus proteins.

DC-SIGN is a pattern recognition receptor predominantly expressed on the surface of dendritic cells and macrophages [171]. It serves as an attachment factor for various types of viruses, including alphavirus (CHIKV [37]), flavivirus (DENV [172], JEV [173], HCV [174], WNV [175], and ZIKV [37]), filovirus (EBOV [176]), herpesvirus (CMV/HHV-5 [175], and Kaposi's sarcoma herpes virus [177]), orthomyxovirus (influenza virus [178]), retrovirus (human immunodeficiency virus 1 (HIV-1) and HIV-2 $[179,180]$ ), and coronavirus (human coronavirus 229E [181], SARS-CoV and SARS-CoV-2 [175,182-184]). Polymorphism in DC-SIGN was reported as a risk factor for CHIKV infection and pathology [185]. This phenomenon is based on an alteration of the CD209 promoter gene (A/G (rs4804803) at position 336) and the greater frequency of this genotype in Chikungunya-infected patients compared to healthy controls $[171,186]$. Peer-reviewed publications have reported that DC-SIGN is important for the attachment and internalization steps of both alphaviruses and flaviviruses [187-190]. Interference with DC-SIGN activity can inhibit virus infection and is thus a potential target for novel antiviral therapies. In 2014, Varga and his team synthesized multivalent Man glycodendrimers to compete with virus E protein for DC-SIGN interaction [191].

Among multivalents, the hexavalent-glycodendrimer has demonstrated the highest inhibition activity for HIV and DENV2 infection in B-THP-1 and Raji cells with DC-SIGNoverexpression, respectively. This information could inform the discovery of specific molecules that can compete with the binding of viral E protein to DC-SIGN on host cells. In contrast to mimicking viral E protein production, inhibitors directly targeting viral E proteins were discovered. Three plant lectins (Galanthus nivalis agglutinin (GNA), Hippeastrum hybrid agglutinin (HHA), and Urtica dioica (UDA) isolated from the amaryllis) 
were reported as DENV envelope protein binding agents that were subsequently found to prevent virus-DC-SIGN attachment [192]. Recently, Prado Acosta and team announced that DC-SIGN-overexpressed cells show significantly enhanced CHIKV and ZIKV infections, confirming DC-SIGN's function as a virus attachment factor. There was a report that the interaction between the surface layer (S-layer) proteins of Lactobacillus acidophilus (a bacteria in the human intestine) and DC-SIGN markedly inhibits H9N2 and Junin viral infections [193,194]. A further investigation of the S-layer's inhibition ability found that blocking DC-SIGN by pretreating cells with the S-layer significantly decreases CHIKV and ZIKV infectivity in a dose-dependent manner [37]. However, further study is needed to clarify the inhibitory mechanisms of the S-layer.

Table 1. Summary of known host factors that interact with Chikungunya virus proteins. NLS: nuclear localization signal; NES: nuclear exportation signals; E: envelope; nsP: non-structural protein; GAGs: glycosaminoglycans; hTIM: human T cell immunoglobulin mucin; AXL: Axl receptor tyrosine kinase; Mxra8: matrix remodeling-associated protein 8; DC-SIGN: dendritic-cell-specific ICAM-grabbing non-integrin; ER: endoplasmic reticulum.

\begin{tabular}{|c|c|c|c|c|}
\hline $\begin{array}{l}\text { Viral Protein } \\
\text { (Binding Site) }\end{array}$ & Host Factor/Protein & Host Factor/Protein Function & $\begin{array}{l}\text { Host Factor/Protein Involves } \\
\text { in Viral Replication }\end{array}$ & Reference \\
\hline $\begin{array}{l}\text { Capsid } \\
\text { (NLS) }\end{array}$ & $\begin{array}{l}\text { Kar } \alpha 4 / \text { major } \\
\text { binding site }\end{array}$ & $\begin{array}{l}\text { Molecule transportation between } \\
\text { nucleus and cytoplasm. }\end{array}$ & $\begin{array}{l}\text { Allow for virus capsid for } \\
\text { nuclear translocation. }\end{array}$ & [16] \\
\hline $\begin{array}{l}\text { Capsid (NES, } \\
\text { aa } 143-155)\end{array}$ & CRM1 (XPO1)/NR & $\begin{array}{l}\text { RNA and protein exportation from the } \\
\text { nucleus to cytoplasm. }\end{array}$ & $\begin{array}{l}\text { Exit virus capsid from the } \\
\text { nucleus. }\end{array}$ & [16] \\
\hline E3 & Furin & $\begin{array}{l}\text { Serine endoprotease with } \\
\text { calcium-dependent favor cleaving the } \\
\text { paired basic amino acids. }\end{array}$ & Cleave E3 from pE2-E1 dimer. & [195] \\
\hline E2 & PHB & $\begin{array}{l}\text { Various functions, with an especially } \\
\text { critical role in proteins and lipids } \\
\text { regulating mitochondrial metabolism. }\end{array}$ & Attach and entry factors. & {$[40]$} \\
\hline E2 & GAGs & $\begin{array}{l}\text { Cellular process regulation including } \\
\text { cell signaling. }\end{array}$ & Attach and entry factors. & [18] \\
\hline E2 & hTIM1 & $\begin{array}{l}\text { Human immune response, apoptotic } \\
\text { cell engulfment, and T cell } \\
\text { proliferation regulation. }\end{array}$ & Attach and entry factors. & [39] \\
\hline E2 & AXL & $\begin{array}{c}\text { Cellular process involvement and } \\
\text { regulation. }\end{array}$ & Attach and entry factors. & {$[39]$} \\
\hline E2 & Mxra8 & $\begin{array}{l}\text { Modulates the activity of various } \\
\text { signaling pathways. }\end{array}$ & Attach and entry factors. & [41] \\
\hline E2 & DC-SIGN & $\begin{array}{l}\text { Involved in dendritic cell } \\
\text { differentiation, cell adhesion, } \\
\text { signaling, migration, and antigen } \\
\text { recognition. }\end{array}$ & Attach and entry factors. & [37] \\
\hline E2 & PTPN2 & $\begin{array}{l}\text { A tyrosine phosphatase involved in } \\
\text { numerous signaling events. }\end{array}$ & $\begin{array}{l}\text { Transport virus structural } \\
\text { protein to host cell membrane. }\end{array}$ & [196] \\
\hline E2 & COL1A2 & $\begin{array}{l}\text { Type I collagen that strengthens and } \\
\text { supports many tissues in the body. }\end{array}$ & Mechanism unknown. & [196] \\
\hline E2 & ACTG1 & Part of cellular trafficking machinery. & $\begin{array}{l}\text { Transport virus structural } \\
\text { protein to host cell membrane. }\end{array}$ & [196] \\
\hline $6 \mathrm{~K} / \mathrm{TF}$ & - & - & - & - \\
\hline E1 & COMMD1 & $\begin{array}{l}\text { Regulation of cellular protein } \\
\text { degradation and ubiquitination. }\end{array}$ & $\begin{array}{l}\text { Transport virus structural } \\
\text { protein to host cell membrane } \\
\text { and regulate host immune } \\
\text { responses. }\end{array}$ & [196] \\
\hline E1 & THBS1 & $\begin{array}{l}\text { Involved in dentinogenesis and ER } \\
\text { stress responses. }\end{array}$ & $\begin{array}{l}\text { Involved in the regulation of } \\
\text { host immune responses. }\end{array}$ & [196] \\
\hline
\end{tabular}


Table 1. Cont

\begin{tabular}{|c|c|c|c|c|}
\hline $\begin{array}{l}\text { Viral Protein } \\
\text { (Binding Site) }\end{array}$ & Host Factor/Protein & Host Factor/Protein Function & $\begin{array}{l}\text { Host Factor/Protein Involves } \\
\text { in Viral Replication }\end{array}$ & Reference \\
\hline E1 & DYNC1H1 & $\begin{array}{l}\text { Transfer material such as neurons } \\
\text { across cells and important in cell } \\
\text { division. }\end{array}$ & $\begin{array}{l}\text { Transport virus structural } \\
\text { proteins to host cell membrane } \\
\text { and related to neurological } \\
\text { manifestation. }\end{array}$ & [196] \\
\hline E1 & ATP1B3 & $\begin{array}{l}\text { Sodium/potassium-transporting } \\
\text { ATPase. }\end{array}$ & Fusion factors. & [196] \\
\hline E1 & BST-2 & $\begin{array}{l}\text { Antiviral response by blocking mature } \\
\text { virion budding from host cell. }\end{array}$ & Budding factors. & [23] \\
\hline nsP1 & BST-2 & $\begin{array}{l}\text { Antiviral response by blocking mature } \\
\text { virion budding from host cell. }\end{array}$ & Budding factors. & [23] \\
\hline $\mathrm{nsP2}$ & Rpb1 & Catalyse RNA transcription. & $\begin{array}{l}\text { nsP2 induces Rpb1 } \\
\text { degradation, leading to the } \\
\text { inhibition of cellular } \\
\text { transcription and antiviral } \\
\text { responses. }\end{array}$ & [197] \\
\hline nsP2 & SFRS3/SRp20 & $\begin{array}{l}\text { Involved in mRNA exportation from } \\
\text { the nucleus and RNA splicing. }\end{array}$ & Mechanism unknown. & [198] \\
\hline nsP2 & $\begin{array}{l}\text { CCDC130, CPNE6, } \\
\text { POLR2C, MAPK9, } \\
\text { EIF4A2, EEF1A1, } \\
\text { EIF3I }\end{array}$ & $\begin{array}{c}\text { Putative interactors with nsP2 and } \\
\text { mainly involved in apoptosis, } \\
\text { transcription, and translation } \\
\text { mechanism. }\end{array}$ & Mechanism unknown. & [199] \\
\hline nsP2 & $\begin{array}{l}\text { CEP55, KLC4, } \\
\text { TACC3, VIM }\end{array}$ & Component of cytoskeleton. & $\begin{array}{l}\text { Support the formation of } \\
\text { replication complex and help } \\
\text { to transport in the infected } \\
\text { cells. }\end{array}$ & [198] \\
\hline nsP2 & HNRNPK & $\begin{array}{l}\text { Important role in mRNA metabolism, } \\
\text { DNA damaging, and activating and } \\
\text { controlling the transcription process. }\end{array}$ & Promotes viral replication. & [198] \\
\hline nsP2 & TTC7B & $\begin{array}{l}\text { Regulate and localize } \\
\text { phosphatidylinositol 4-kinase to the } \\
\text { cell membrane. }\end{array}$ & $\begin{array}{l}\text { Support nsP2 for shutting off } \\
\text { the cellular processing of host } \\
\text { cells. }\end{array}$ & [198] \\
\hline nsP2 & $\begin{array}{c}\text { ASCC2, EWSR1, } \\
\text { IKZF1, TRIM27, } \\
\text { ZBTB43, } \\
\text { MRFAP1L1(MRG15) }\end{array}$ & $\begin{array}{l}\text { ASCC2: Support gene transcription } \\
\text { and repairing. } \\
\text { EWSR1: Involved in cell signaling, } \\
\text { gene expression. and RNA processing } \\
\text { and transport. } \\
\text { IKZF1: A transcription factor. } \\
\text { TRIM27: Control gene transcription. } \\
\text { MRFAP1L1(MRG15): Regulate } \\
\text { transcription by the binding with } \\
\text { retinoblastoma tumor suppressor (Rb) } \\
\text { and MORF4/MRG nuclear protein } \\
\text { PAM14. } \\
\text { ZBTB43: Suppress Blimp1 } \\
\text { transcription process. }\end{array}$ & Mechanism unknown. & [198] \\
\hline $\mathrm{nsP2}$ & $\begin{array}{l}\text { UBQLN4, RCHY1, } \\
\text { WWP1 }\end{array}$ & $\begin{array}{l}\text { Involved in protein degradation and } \\
\text { autophagy. }\end{array}$ & Promotes viral replication. & [198] \\
\hline
\end{tabular}


Table 1. Cont

\begin{tabular}{|c|c|c|c|c|}
\hline $\begin{array}{l}\text { Viral Protein } \\
\text { (Binding Site) }\end{array}$ & Host Factor/Protein & Host Factor/Protein Function & $\begin{array}{l}\text { Host Factor/Protein Involves } \\
\text { in Viral Replication }\end{array}$ & Reference \\
\hline nsP2 & $\begin{array}{l}\text { GFAP, PDK2, } \\
\text { RBM12B, TPR }\end{array}$ & $\begin{array}{l}\text { GFAP: A cell-specific marker helps to } \\
\text { differentiate astrocytes from other } \\
\text { glial cells. } \\
\text { PDK2: Regulate glucose and fatty acid } \\
\text { metabolism and homeostasis, cell } \\
\text { proliferation, and delay apoptosis. } \\
\text { RBM12B: RNA-binding protein. } \\
\text { TPR: Support protein and mRNA } \\
\text { transportation from the nucleus. }\end{array}$ & Mechanism unknown. & [198] \\
\hline nsP2 & NDP52/CALCOCO2 & $\begin{array}{l}\text { Involved in autophagy, inhibit } \\
\text { pathogen proliferation. }\end{array}$ & $\begin{array}{l}\text { Support the replication } \\
\text { complexes formation. }\end{array}$ & [198] \\
\hline nsP3 & $\begin{array}{l}\text { PI3K-Akt-mTOR } \\
\text { pathway }\end{array}$ & $\begin{array}{l}\text { Involved in cellular proliferation and } \\
\text { regulate cell cycle. }\end{array}$ & $\begin{array}{l}\text { Support the replication } \\
\text { complexes internalization. }\end{array}$ & [200] \\
\hline nsP3 & G3BP1 and G3BP2 & $\begin{array}{l}\text { G3BP1: Can be used as stress granule } \\
\text { marker and to facilitate stress granule } \\
\text { assembly. } \\
\text { G3BP2: Could transport mRNA. }\end{array}$ & Mediate viral replication. & [201] \\
\hline nsP3 & SK2 & $\begin{array}{l}\text { Involved in cell proliferation, } \\
\text { differentiation, and host cell } \\
\text { immunity. }\end{array}$ & Mediate viral replication. & [202] \\
\hline nsP3 & Hsp $90 \beta$ & $\begin{array}{l}\text { Maintain cellular homeostasis by } \\
\text { modulating cellular processes. }\end{array}$ & Mechanism unclear. & [203] \\
\hline nsP4 & LCP1 & $\begin{array}{l}\text { Involved in T cell activation } \\
\text { mechanisms. }\end{array}$ & Mechanism unknown. & [198] \\
\hline $\mathrm{nsP} 4$ & Hsp90 $\alpha$ & $\begin{array}{l}\text { Maintains cellular homeostasis by } \\
\text { modulating cellular processes. }\end{array}$ & $\begin{array}{l}\text { Support replication complex } \\
\text { formation. }\end{array}$ & [203] \\
\hline $\mathrm{nsP} 4$ & $\mathrm{eIF} 2 \alpha$ & Important for translation process. & Mediate the viral replication. & [204] \\
\hline
\end{tabular}

Table 2. Summary of known host factors which interact with Zika virus proteins. TBK: TANK binding kinase 1; IRF: interferon regulator factor; MAVS: mitochondrial antiviral-signaling; NS: non-structural protein; MTase: methyltransferase; IFN: interferon; MDA5: melanoma differentiation-associated protein 5; RIG-1: retinoic acid-inducible gene-I.

\begin{tabular}{cccc}
\hline $\begin{array}{c}\text { Viral Protein } \\
\text { (Binding Site) }\end{array}$ & Host Factor/Protein & Host Factor/Protein Function & $\begin{array}{c}\text { Host Factor/Protein Involves } \\
\text { in Viral Replication }\end{array}$ \\
\hline $\begin{array}{c}\text { Capsid } \\
\text { (Positively } \\
\text { charged } \\
\text { interface } \\
\text { formed by } \alpha 4 \\
\text { helix) }\end{array}$ & $\begin{array}{c}\text { Nucleotides } \\
\text { (single-stranded and } \\
\text { double-stranded } \\
\text { RNAs or DNAs) }\end{array}$ & DNA synthesis. & Mechanism unknown. \\
\hline $\begin{array}{c}\text { Capsid } \\
\text { pre- } \alpha 1 \text { loop) }\end{array}$ & Lipid droplets & Not reported. & [205] \\
\hline Capsid & G3BP1 and Caprin-1 & $\begin{array}{c}\text { G3BP1: Essential in innate } \\
\text { immune response. } \\
\text { Caprin-1: Regulates mRNAs } \\
\text { transportation and translation and is } \\
\text { involved in neuron synaptic and cell } \\
\text { proliferation and migration. }\end{array}$ & $\begin{array}{c}\text { The interaction facilitates viral } \\
\text { replication and also impairs } \\
\text { stress granule formation. }\end{array}$ \\
\hline [206]
\end{tabular}


Table 2. Cont

\begin{tabular}{|c|c|c|c|c|}
\hline $\begin{array}{l}\text { Viral Protein } \\
\text { (Binding Site) }\end{array}$ & Host Factor/Protein & Host Factor/Protein Function & $\begin{array}{l}\text { Host Factor/Protein Involves } \\
\text { in Viral Replication }\end{array}$ & Reference \\
\hline PrM/M (PrM) & Furin & $\begin{array}{l}\text { Serine endoprotease with } \\
\text { calcium-dependent favor cleaving the } \\
\text { paired amino acids. }\end{array}$ & $\begin{array}{l}\text { Facilitate the viral maturation } \\
\text { process. }\end{array}$ & [208] \\
\hline E (DII) & $\begin{array}{l}\text { Endoplasmic } \\
\text { membrane }\end{array}$ & $\begin{array}{l}\text { Synthesis, folding, modification, and } \\
\text { transport of proteins. }\end{array}$ & Membrane fusion. & [55] \\
\hline E (DIII) & Endosome & $\begin{array}{l}\text { Regulate the transportation of } \\
\text { proteins and lipids among cellular } \\
\text { compartments of the endocytic } \\
\text { pathway. }\end{array}$ & Membrane fusion. & [55] \\
\hline $\mathrm{E}$ & $\begin{array}{l}\text { DC-SIGN, HSP70, } \\
\text { TIM-1 and TAM } \\
\text { receptors (TYRO3, } \\
\text { AXL, and MER) }\end{array}$ & $\begin{array}{c}\text { DC-SIGN: dendritic cell } \\
\text { differentiation, cell adhesion, } \\
\text { signaling, migration, and antigen } \\
\text { recognition. } \\
\text { TIM-1: regulates human immune } \\
\text { response, cell survival, and the } \\
\text { clearance of apoptotic cells. } \\
\text { HSP70: involved in protein folding } \\
\text { and unfolding regulation and protects } \\
\text { the cell from oxidative stress. } \\
\text { TAM receptors: involved in many } \\
\text { cellular processes including cell } \\
\text { differentiation, cell survival, } \\
\text { migration, and innate immune } \\
\text { modulation. }\end{array}$ & $\begin{array}{l}\text { DC-SIGN and TIM-1: involved } \\
\text { in viral entry. } \\
\text { HSP70: mediate viral entry, } \\
\text { replication, and release. } \\
\text { TAM receptors: involved in } \\
\text { viral entry and innate immune } \\
\text { responses modulation. }\end{array}$ & $\begin{array}{l}{[71,209-} \\
214]\end{array}$ \\
\hline $\mathrm{E}$ & Mfsd2a & $\begin{array}{l}\text { Support blood-brain barrier } \\
\text { formation and function. }\end{array}$ & Impaired brain development & [215] \\
\hline NS1 & TBK1 & $\begin{array}{l}\text { Regulates inflammatory responses to } \\
\text { foreign agents. }\end{array}$ & Blocks IFN signaling & [216] \\
\hline \multirow[t]{2}{*}{ NS2A } & TBK1 & $\begin{array}{c}\text { Regulates inflammatory responses to } \\
\text { foreign agents. }\end{array}$ & Blocks IFN signaling. & {$[61]$} \\
\hline & IRF3 & $\begin{array}{l}\text { Transcriptional regulator of type I } \\
\text { IFN-dependent immune responses. }\end{array}$ & $\begin{array}{l}\text { Inhibits the production of type } \\
\text { I IFN induced by MDA5/RIG-I } \\
\text { signaling pathway. }\end{array}$ & [217] \\
\hline NS2B & TBK1 & $\begin{array}{c}\text { Regulates inflammatory responses to } \\
\text { foreign agents }\end{array}$ & Blocks IFN signaling. & {$[61,216]$} \\
\hline \multirow[t]{2}{*}{ NS2B $/ 3$} & SEPT2 & $\begin{array}{l}\text { Involved in actin cytoskeleton } \\
\text { organization. }\end{array}$ & $\begin{array}{l}\text { Trigger cell death and stress in } \\
\text { hNPC. }\end{array}$ & [208] \\
\hline & Jak1 & $\begin{array}{l}\text { Involved in interleukin-2 and } \\
\text { interleukin-10 receptors. }\end{array}$ & Suppress JAK-STAT signaling. & [216] \\
\hline \multirow[t]{2}{*}{ NS4A } & MAVS & $\begin{array}{l}\text { Required for innate immune defense } \\
\text { against viruses. }\end{array}$ & Blocks the IFN signaling. & {$[218,219]$} \\
\hline & IRF3 & $\begin{array}{l}\text { Transcriptional regulator of type I } \\
\text { IFN-dependent immune responses. }\end{array}$ & $\begin{array}{l}\text { Inhibits the production of type } \\
\text { I IFN induced by MDA5/RIG-I } \\
\text { signaling pathway. }\end{array}$ & [217] \\
\hline NS4B & TBK1 & $\begin{array}{c}\text { Regulates inflammatory responses to } \\
\text { foreign agents. }\end{array}$ & Blockis IFN signaling. & {$[61,216]$} \\
\hline NS5 & STAT1 & $\begin{array}{l}\text { Mediated cellular response to IFNs, } \\
\text { cytokines, and growth factors. }\end{array}$ & Blocks IFN signaling. & [220] \\
\hline $\begin{array}{c}\text { NS5 } \\
\text { (MTase domain) }\end{array}$ & STAT2 & $\begin{array}{l}\text { Mediated IFN-alpha and IFN-beta } \\
\text { signaling. }\end{array}$ & Blocks IFN signaling. & [68] \\
\hline
\end{tabular}


hTIM-1 (human T-cell immunoglobulin and mucin 1) is a human TIM protein from a family of phosphatidylserine (PS) receptors that are mainly expressed in Thelper (Th) 2 cells, kidney epithelia, and a broad range of mucosal epithelia including the trachea, conjunctiva, and cornea [221,222]. hTIM-1 is reported to be a receptor for attachment by various enveloped viruses [39]. Kondratowicz and team documented that TIM-1 acts as an EBOV receptor both in vitro and in vivo. The overexpression of TIM-1 in restricted cell lines significantly enhances EBOV infection, while, in contrast, TIM-1-silenced cells markedly decrease the viral infection of even highly permissive cells [221,222]. In keeping with in vitro results, in vivo experiments with TIM-1-sufficient or -deficient BALB/c mice showed that TIM-1 increases viral load and the associated mortality [223]. These results imply that TIM-1 is essential for, at least, viral entry and pathogenesis. Recently, Ichimura et al. demonstrated that kidney injury molecule- $1 / \mathrm{T}$ cell immunoglobulin mucin domain 1 (KIM-1/TIM-1) is a novel receptor for SARS-CoV-2. Virus binding can be blocked by anti-KIM-1 antibody and TW-37, a discovered inhibitor of KIM-1/TIM-1, mediated endocytosis [224]. This result supported the crucial role of TIM- 1 as a virus receptor. The finding of TIM-1 inhibitor(s) may provide an additional modality to prevent or treat COVID-19.

In CHIKV, TIM-1 was identified as an attachment factor that promotes viral infection rather than being a specific receptor. In TIM-1-overexpressed cells, CHIKV infection is moderately enhanced and the transfection of CHIKV-pseudotype viral vectors is slightly inhibited by PS liposomes [38]. Similarly, ZIKV infection is partially decreased by neutralizing $\mathrm{Ab}$ specific for TIM-1 and by an RNA silencing technique to downregulate TIM-1 before virus infection [71]. However, the downregulation of TIM-1 together with AXL expression in A549 cells totally abrogated ZIKV infection. These data suggested that TIM-1 is a co-factor for the viral attachment and entry of CHIKV and ZIKV. Though TIM-1 was reported to be a virus receptor or attachment factor for a long time, data regarding its inhibitors are limited. Li and team found that HIV-1 Nef proteins and lentivirus accessory proteins antagonize TIM-mediated cell restriction, while, SERINC5 host cell restriction factors stabilized the expression of TIM-1 [225].

However, the mechanisms of the Nef inhibition of TIM-1 need to be further investigated. Therefore, the investigation of TIM- 1 and its inhibitors impact upon virus interactions may help to develop effective antivirals that could reduce viral load and severity during virus infection.

The TAM receptor family consists of transmembrane receptor protein tyrosine kinases (PTKs) that regulate PTK activity within their cytoplasmic domains. The name "TAM" derives from the first letter of its three members: Tyro3, Axl, and Mer [226]. Axl is reported to enhance EBOV and MARV in the entry step [227]. Likewise, Axl also promotes the CHIKV infection of hAxl-293T-overexpressed cells. The proposed mechanism is that Axl binds and internalizes various viruses through PS-binding bridging proteins (Gas6 and/or Protein S) in serum [39].

Axl is highly expressed in several types of ZIKV-permissive cells. In in vitro experiments, Axl acts as a virus attachment factor or as a signaling receptor to enhance virus infection $[71,211,213,228-234]$. In contrast, in vivo experiments have shown that the ZIKV infection of some mice organs (eyes, brain, and testes) is independent of TAM receptors $[209,235]$. Furthermore, the loss of Axl does not impact ZIKV infectivity, as shown in experiments deleting Axl, using CRISPR-Cas9 technology, in human neural progenitor cells and cerebral organoids [236]. Collectively, the data (though inconclusive) presented here suggest that: (1) mice may have entry receptors/attachment factors that are not expressed in human cells or (2) human cells do not recapitulate the expression of a wide range of virus entry receptors/attachment factors. Finding the relevant entry receptors/attachment factors will be essential for a more complete understanding of ZIKV virology and cell tropism.

Furthermore, Wang et al. recently reported that Axl is a candidate receptor of SARSCoV-2. They used both pseudotype and wild-type SARS-CoV-2, and they found that AxlHEK293T-overexpressed cells have enhanced virus infection while Axl-H1299-depleted cells had markedly reduced viral infection [237]. This emphasized the significance of Axl 
in a wide range of virus receptors in humans. These data implied that TIM and TAM, PS-binding proteins, promote infection by diverse families of enveloped viruses and are, therefore, candidate targets for broad-spectrum antiviral therapies.

\subsection{Host Cell Immune Responses and Viral Immune Evasion Mechanisms}

Initially, upon virus infection, host innate immune systems sense single or doublestranded (ss or ds) RNAs in infected cells by pathogen-associated molecular pattern (PAMP) recognition. For example, retinoic acid-inducible gene-I (RIG-I) recognizes short 5'-triphosphorylated ssRNA and short dsRNA, and melanoma differentiation-associated protein 5 (MDA5) participates in the recognition of longer dsRNA products [238-240]. Using a PCR array and qRT-PCR, our team reported that IFIH1 (MDA5) was upregulated during wild-type CHIKV infection in human skin fibroblasts and that the expression level was downregulated when infected in the presence of mosquito saliva [241]. Using CHIKV proteins cloned into an expression vector, nsP2, E1, and E2 were found to strongly downregulate MDA5, while nsP2 and E1 (but not E2) inhibited RIG-I [242]. This information implicates MDA5 and RIG-I as major sensors of CHIKV infection that can be blocked by nsP2 and E1 virus proteins. In ZIKV infection, MDA5 and RIG-I expression levels are upregulated in human skin fibroblasts as soon as $6 \mathrm{hpi}$, with the highest levels at $48 \mathrm{hpi}$ [71]. Moreover, both MDA5 and RIG-I expression levels can be inhibited by NS2A and NS4A of ZIKV in HEK293T cells [217]. Interestingly, Schilling and team announced that only RIG-I functions as a ZIKV detector because the knockout of RIG-I, but not of MDA5, significantly increases virus replication [243]. As $14-3-3 \epsilon$ and $14-3-3 \eta$ proteins promote MDA5 and RIG-I cytosolic-to-mitochondrial translocation, the inhibition of these proteins inhibits downstream RIG-I-like receptor (RLR) signaling. Recently, Riedl and team found that the ZIKV NS3 protein suppresses antiviral signaling via the binding of MDA5 and RIG-I to

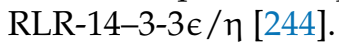

Upon the ligand binding of MDA5 and RIG-I, they mediate downstream signal activation through caspase recruitment domain (CARD)-CARD interactions [245]. MDA5 and RIG-I activate mitochondrial antiviral-signaling (MAVS) via its N-terminal CARD that subsequently activates the downstream kinase proteins TBK1 and inhibitor of kappa-B kinase epsilon $(\mathrm{IKK} \varepsilon)$. Vice versa, the protein activates interferon regulator factor (IRF)-3 and nuclear factor kappa B (NF-kB) [246]. The activation of IRF3 or IRF7 and NF-kB induces IFN- $\beta$ production. Consequently, the triggering of the type I IFN canonical pathway through JAK-STAT signaling results in an ISGF3 complex (STAT1-STAT2-IRF9) assembly that then translocates into the nucleus to activate IFN-stimulated gene (ISG) transcription [247].

Downstream signaling is essential to inhibit both CHIKV and ZIKV infections. However, the viruses have mechanisms to evade IFN responses. Our team documented (using qRT-PCR, PCR array, and Western blot techniques) that the expression level of STAT2 is significantly increased in CHIKV-infected human fibroblasts and markedly decreased in the presence of Aedes mosquito saliva [241]. These data imply that Aedes saliva affects host cell immune responses to CHIKV infection via, at least, the JAK-STAT-dependent pathway. Recently, Bae and colleagues found that the transfection of CHIKV nsP2, E2 and E1 proteins into HEK293T cells significantly inhibits the downstream signaling of MAVS, TBK1, and IKK $\varepsilon$ and diminishes NF- $K B$ activation [242]. In addition, a report showed that MAVS knockout-human placental trophoblast cell lines enhance ZIKV infection [219]. NS1 and NS4B overexpression can directly interact with TBK1, preventing TBK1 oligomerization and phosphorylation [216].

In another study, ZIKV NS5-HEK293-overexpressed cells directly interacted with IKK $\varepsilon$ and prevented IRF3 activation [248]. NS5 is also reported to directly bind with endogenous IRF3 and inhibit downstream signaling [61]. Distinct evading mechanisms of ZIKV in the JAK-STAT signaling pathway are characterized by ZIKV NS5 protein-STAT2 protein degradation. The NS5 protein binds and degrades STAT2 in a proteasome-dependent manner [68]. Hertzog and team found that NS5 blocked JAK-STAT signaling via the reduction of STAT2 levels, thus blocking STAT1 phosphorylation [249]. A study also demonstrated 
that ZIKV NS2B and NS3 inhibited JAK-STAT signaling through the degradation of JAK1 protein in proteasomes, resulting in a reduction of IFN-mediated ISG expression [216].

\subsection{Updating Host-Targeting Antivirals}

Cavinafungin, a linear lipopeptide isolated from Colispora cavincola [250], specifically and strongly inhibits ZIKV infection (with IC50 $=0.15 \mu \mathrm{M}$ and CC50 $=1.65 \mu \mathrm{M}$ ), but it is not effective against CHIKV infection. Using CRISPR/Cas9 gene-editing strategies, it could be determined that cavinafungin targets the host cell's endoplasmic reticulum-localized signal peptidase (ER-SPase) [251]. Actually, in the ZIKV replication cycle, ER-SPase plays a crucial role in $\mathrm{prM} / \mathrm{E}$ processing, while the replication of CHIKV mainly occurs in the cytoplasm. This may explain why cavinafungin can be effectively inhibited by ZIKV but not CHIKV. The further study of the function of the ER-SPase in ZIKV polyprotein processing may pave the way for novel ZIKV inhibitor development.

Recently, Prochnow et al. reported that labyrinthopeptins exhibit broad-spectrum antiviral activity mediated by virolysis. Labyrinthopeptins A1 and A2, posttranslational modification peptides isolated from the actinomycete Actinomadura namibiensis DSM 6313, are class III lanthipeptides [252,253]. Cell lines pretreated with different concentrations of the compounds before infection by CHIKV and ZIKV inhibit virus infection in the low micromolar-to-nanomolar range. A study of the peptide's mechanism using 11 species of adsorbed lipids demonstrated that the virolysis effect occurred through the binding of labyrinthopeptins and lipid phosphatidylethanolamine to the viral membrane [254]. However, in vivo experiments of labyrinthopeptins are still needed.

\section{Conclusions}

In the past few decades, the wide spread of Chikungunya and Zika viruses has highlighted the urgent need for effective antiviral drugs to treat patients and prevent future outbreaks. Several host factors that interact with viral proteins have been identified (Tables 1 and 2). Nevertheless, the mechanisms of the interplay between virus and host factors during virus infection need further investigation. Such study will expand knowledge and bring more opportunities and ideas for the further development, optimization, and speeding up of the discovery or repurpose of potential therapeutic drugs to counter such re-emerging arboviruses.

Author Contributions: Conceptualization: S.W., N.G. and D.M.; writing—original draft preparation: S.W. and N.G.; review and editing: S.W., N.G., R.H., S.A., S.Y., C.P. and D.M.; supervision, S.W. All authors have read and agreed to the published version of the manuscript. Authorship is limited to those who have contributed substantially to the work reported.

Funding: This work was financially supported by Walailak University (Contract No. Wu-CGS-62002) and the French National Research Agency (ANR-15-CE15-00029).

Acknowledgments: We thank Thanyakorn Rongsawat for technical assistance.

Conflicts of Interest: The authors declare they have no conflicts of interest.

\section{References}

1. Oster, A.M.; Brooks, J.T.; Stryker, J.E.; Kachur, R.E.; Mead, P.; Pesik, N.T.; Petersen, L.R. Interim Guidelines for Prevention of Sexual Transmission of Zika Virus-United States, 2016. MMWR Morb. Mortal. Wkly. Rep. 2016, 65, 120-121. [CrossRef]

2. Briant, L.; Desprès, P.; Choumet, V.; Missé, D. Role of skin immune cells on the host susceptibility to mosquito-borne viruses. Virology 2014, 464-465, 26-32. [CrossRef]

3. Cunha, R.V.D.; Trinta, K.S. Chikungunya virus: Clinical aspects and treatment-A Review. Memórias Inst. Oswaldo Cruz 2017, 112, 523-531. [CrossRef]

4. Hamel, R.; Liégeois, F.; Wichit, S.; Pompon, J.; Diop, F.; Talignani, L.; Thomas, F.; Desprès, P.; Yssel, H.; Missé, D. Zika virus: Epidemiology, clinical features and host-virus interactions. Microbes Infect. 2016, 18, 441-449. [CrossRef]

5. Ferraris, P.; Yssel, H.; Missé, D. Zika virus infection: An update. Microbes Infect. 2019, 21, 353-360. [CrossRef]

6. Hucke, F.I.L.; Bugert, J.J. Current and Promising Antivirals Against Chikungunya Virus. Front. Public Health $2020,8,618624$. [CrossRef] [PubMed] 
7. Wong, K.Z.; Chu, J.J.H. The Interplay of Viral and Host Factors in Chikungunya Virus Infection: Targets for Antiviral Strategies. Viruses 2018, 10, 294. [CrossRef] [PubMed]

8. Lin, K.; Gallay, P. Curing a viral infection by targeting the host: The example of cyclophilin inhibitors. Antivir. Res. 2013, 99, 68-77. [CrossRef] [PubMed]

9. Schneider, A.B.; Ochsenreiter, R.; Hostager, R.; Hofacker, I.L.; Janies, D.; Wolfinger, M.T. Updated Phylogeny of Chikungunya Virus Suggests Lineage-Specific RNA Architecture. Viruses 2019, 11, 798. [CrossRef] [PubMed]

10. Yap, M.L.; Klose, T.; Urakami, A.; Hasan, S.S.; Akahata, W.; Rossmann, M.G. Structural studies of Chikungunya virus maturation. Proc. Natl. Acad. Sci. USA 2017, 114, 13703-13707. [CrossRef] [PubMed]

11. Khan, A.H.; Morita, K.; Parquet, M.D.C.; Hasebe, F.; Mathenge, E.G.M.; Igarashi, A. Complete nucleotide sequence of chikungunya virus and evidence for an internal polyadenylation site. J. Gen. Virol. 2002, 83, 3075-3084. [CrossRef]

12. Forrester, N.L.; Palacios, G.; Tesh, R.B.; Savji, N.; Guzman, H.; Sherman, M.; Weaver, S.C.; Lipkin, W.I. Genome-scale phylogeny of the alphavirus genus suggests a marine origin. J. Virol. 2012, 86, 2729-2738. [CrossRef]

13. Singh, A.; Kumar, A.; Uversky, V.; Giri, R. Understanding the interactability of chikungunya virus proteins viamolecular recognition feature analysis. RSC Adv. 2018, 8, 27239-27303. [CrossRef]

14. Sun, S.; Xiang, Y.; Akahata, W.; Holdaway, H.; Pal, P.; Zhang, X.; Diamond, M.S.; Nabel, G.J.; Rossmann, M.G. Structural analyses at pseudo atomic resolution of Chikungunya virus and antibodies show mechanisms of neutralization. eLife 2013, 2, e00435. [CrossRef] [PubMed]

15. Taylor, A.; Liu, X.; Zaid, A.; Goh, L.Y.; Hobson-Peters, J.; Hall, R.A.; Merits, A.; Mahalingam, S. Mutation of the N-Terminal Region of Chikungunya Virus Capsid Protein: Implications for Vaccine Design. mBio 2017, 8. [CrossRef] [PubMed]

16. Thomas, S.; Rai, J.; John, L.; Schaefer, S.; Pützer, B.M.; Herchenröder, O. Chikungunya virus capsid protein contains nuclear import and export signals. Virol. J. 2013, 10, 269. [CrossRef] [PubMed]

17. Voss, J.E.; Vaney, M.C.; Duquerroy, S.; Vonrhein, C.; Girard-Blanc, C.; Crublet, E.; Thompson, A.; Bricogne, G.; Rey, F.A. Glycoprotein organization of Chikungunya virus particles revealed by X-ray crystallography. Nature 2010, 468, 709-712. [CrossRef]

18. Weber, C.; Berberich, E.; von Rhein, C.; Henß, L.; Hildt, E.; Schnierle, B.S. Identification of Functional Determinants in the Chikungunya Virus E2 Protein. PLoS Negl. Trop. Dis. 2017, 11, e0005318. [CrossRef]

19. Snyder, A.J.; Mukhopadhyay, S. The alphavirus E3 glycoprotein functions in a clade-specific manner. J. Virol. 2012, 86, 13609-13620. [CrossRef]

20. Taylor, A.; Melton, J.V.; Herrero, L.J.; Thaa, B.; Karo-Astover, L.; Gage, P.W.; Nelson, M.A.; Sheng, K.C.; Lidbury, B.A.; Ewart, G.D.; et al. Effects of an In-Frame Deletion of the 6k Gene Locus from the Genome of Ross River Virus. J. Virol. 2016, 90, 4150-4159. [CrossRef]

21. Snyder, J.E.; Kulcsar, K.A.; Schultz, K.L.; Riley, C.P.; Neary, J.T.; Marr, S.; Jose, J.; Griffin, D.E.; Kuhn, R.J. Functional characterization of the alphavirus TF protein. J. Virol. 2013, 87, 8511-8523. [CrossRef] [PubMed]

22. Delang, L.; Li, C.; Tas, A.; Quérat, G.; Albulescu, I.C.; De Burghgraeve, T.; Guerrero, N.A.; Gigante, A.; Piorkowski, G.; Decroly, E.; et al. The viral capping enzyme nsP1: A novel target for the inhibition of chikungunya virus infection. Sci. Rep. 2016, 6, 31819. [CrossRef] [PubMed]

23. Jones, P.H.; Maric, M.; Madison, M.N.; Maury, W.; Roller, R.J.; Okeoma, C.M. BST-2/tetherin-mediated restriction of chikungunya (CHIKV) VLP budding is counteracted by CHIKV non-structural protein 1 (nsP1). Virology 2013, 438, 37-49. [CrossRef]

24. Pastorino, B.A.; Peyrefitte, C.N.; Almeras, L.; Grandadam, M.; Rolland, D.; Tolou, H.J.; Bessaud, M. Expression and biochemical characterization of nsP2 cysteine protease of Chikungunya virus. Virus Res. 2008, 131, 293-298. [CrossRef] [PubMed]

25. Rausalu, K.; Utt, A.; Quirin, T.; Varghese, F.S.; Žusinaite, E.; Das, P.K.; Ahola, T.; Merits, A. Chikungunya virus infectivity, RNA replication and non-structural polyprotein processing depend on the nsP2 protease's active site cysteine residue. Sci. Rep. 2016, 6, 37124. [CrossRef] [PubMed]

26. Das, P.K.; Merits, A.; Lulla, A. Functional cross-talk between distant domains of chikungunya virus non-structural protein 2 is decisive for its RNA-modulating activity. J. Biol. Chem. 2014, 289, 5635-5653. [CrossRef]

27. Karpe, Y.A.; Aher, P.P.; Lole, K.S. NTPase and 5'-RNA triphosphatase activities of Chikungunya virus nsP2 protein. PLoS ONE 2011, 6, e22336. [CrossRef]

28. McPherson, R.L.; Abraham, R.; Sreekumar, E.; Ong, S.E.; Cheng, S.J.; Baxter, V.K.; Kistemaker, H.A.; Filippov, D.V.; Griffin, D.E.; Leung, A.K. ADP-ribosylhydrolase activity of Chikungunya virus macrodomain is critical for virus replication and virulence. Proc. Natl. Acad. Sci. USA 2017, 114, 1666-1671. [CrossRef]

29. Gao, Y.; Goonawardane, N.; Ward, J.; Tuplin, A.; Harris, M. Multiple roles of the non-structural protein 3 (nsP3) alphavirus unique domain (AUD) during Chikungunya virus genome replication and transcription. PLoS Pathog. 2019, 15, e1007239. [CrossRef] [PubMed]

30. Meshram, C.D.; Agback, P.; Shiliaev, N.; Urakova, N.; Mobley, J.A.; Agback, T.; Frolova, E.I.; Frolov, I. Multiple Host Factors Interact with the Hypervariable Domain of Chikungunya Virus nsP3 and Determine Viral Replication in Cell-Specific Mode. J. Virol. 2018, 92. [CrossRef]

31. Chen, M.W.; Tan, Y.B.; Zheng, J.; Zhao, Y.; Lim, B.T.; Cornvik, T.; Lescar, J.; Ng, L.F.P.; Luo, D. Chikungunya virus nsP4 RNA-dependent RNA polymerase core domain displays detergent-sensitive primer extension and terminal adenylyltransferase activities. Antivir. Res. 2017, 143, 38-47. [CrossRef] [PubMed] 
32. Kumar, P.; Kapopara, R.; Patni, M.; Pandya, H.; Jasrai, Y.; Patel, S. Exploring the polymerase activity of chikungunya viral non structural protein 4 (nsP4) using molecular modeling, epharmacophore and docking studies. Int. J. Pharm. Life Sci. (IJPLS) 2012, 3, 1752-1765.

33. Lulla, A.; Lulla, V.; Tints, K.; Ahola, T.; Merits, A. Molecular determinants of substrate specificity for Semliki Forest virus nonstructural protease. J. Virol. 2006, 80, 5413-5422. [CrossRef] [PubMed]

34. Sourisseau, M.; Schilte, C.; Casartelli, N.; Trouillet, C.; Guivel-Benhassine, F.; Rudnicka, D.; Sol-Foulon, N.; Le Roux, K.; Prevost, M.C.; Fsihi, H.; et al. Characterization of reemerging chikungunya virus. PLoS Pathog. 2007, 3, e89. [CrossRef]

35. Hoornweg, T.E.; van Duijl-Richter, M.K.S.; Ayala Nuñez, N.V.; Albulescu, I.C.; van Hemert, M.J.; Smit, J.M. Dynamics of Chikungunya Virus Cell Entry Unraveled by Single-Virus Tracking in Living Cells. J. Virol. 2016, 90, 4745-4756. [CrossRef] [PubMed]

36. Bernard, E.; Solignat, M.; Gay, B.; Chazal, N.; Higgs, S.; Devaux, C.; Briant, L. Endocytosis of chikungunya virus into mammalian cells: Role of clathrin and early endosomal compartments. PLOS ONE 2010, 5, e11479. [CrossRef]

37. Prado Acosta, M.; Geoghegan, E.M.; Lepenies, B.; Ruzal, S.; Kielian, M.; Martinez, M.G. Surface (S) Layer Proteins of Lactobacillus acidophilus Block Virus Infection via DC-SIGN Interaction. Front. Microbiol. 2019, 10, 810. [CrossRef]

38. Moller-Tank, S.; Kondratowicz, A.S.; Davey, R.A.; Rennert, P.D.; Maury, W. Role of the phosphatidylserine receptor TIM-1 in enveloped-virus entry. J. Virol. 2013, 87, 8327-8341. [CrossRef]

39. Jemielity, S.; Wang, J.J.; Chan, Y.K.; Ahmed, A.A.; Li, W.; Monahan, S.; Bu, X.; Farzan, M.; Freeman, G.J.; Umetsu, D.T.; et al. TIM-family proteins promote infection of multiple enveloped viruses through virion-associated phosphatidylserine. PLoS Pathog. 2013, 9, e1003232. [CrossRef] [PubMed]

40. Wintachai, P.; Wikan, N.; Kuadkitkan, A.; Jaimipuk, T.; Ubol, S.; Pulmanausahakul, R.; Auewarakul, P.; Kasinrerk, W.; Weng, W.Y.; Panyasrivanit, M.; et al. Identification of prohibitin as a Chikungunya virus receptor protein. J. Med. Virol. 2012, 84, 1757-1770. [CrossRef]

41. Zhang, R.; Kim, A.S.; Fox, J.M.; Nair, S.; Basore, K.; Klimstra, W.B.; Rimkunas, R.; Fong, R.H.; Lin, H.; Poddar, S.; et al. Mxra8 is a receptor for multiple arthritogenic alphaviruses. Nature 2018, 557, 570-574. [CrossRef] [PubMed]

42. van Duijl-Richter, M.K.S.; Blijleven, J.S.; van Oijen, A.M.; Smit, J.M. Chikungunya virus fusion properties elucidated by singleparticle and bulk approaches. J. Gen. Virol. 2015, 96, 2122-2132. [CrossRef] [PubMed]

43. Aggarwal, M.; Sharma, R.; Kumar, P.; Parida, M.; Tomar, S. Kinetic characterization of trans-proteolytic activity of Chikungunya virus capsid protease and development of a FRET-based HTS assay. Sci. Rep. 2015, 5, 14753. [CrossRef]

44. Chen, K.C.; Kam, Y.W.; Lin, R.T.; Ng, M.M.; Ng, L.F.; Chu, J.J. Comparative analysis of the genome sequences and replication profiles of chikungunya virus isolates within the East, Central and South African (ECSA) lineage. Virol. J. 2013, 10, 169. [CrossRef] [PubMed]

45. Kuno, G.; Chang, G.J.; Tsuchiya, K.R.; Karabatsos, N.; Cropp, C.B. Phylogeny of the genus Flavivirus. J. Virol. 1998, 72, 73-83. [CrossRef]

46. Haddow, A.D.; Schuh, A.J.; Yasuda, C.Y.; Kasper, M.R.; Heang, V.; Huy, R.; Guzman, H.; Tesh, R.B.; Weaver, S.C. Genetic characterization of Zika virus strains: Geographic expansion of the Asian lineage. PLoS Negl. Trop. Dis. 2012, 6, e1477. [CrossRef]

47. Sirohi, D.; Chen, Z.; Sun, L.; Klose, T.; Pierson, T.C.; Rossmann, M.G.; Kuhn, R.J. The 3.8 A resolution cryo-EM structure of Zika virus. Science 2016, 352, 467-470. [CrossRef]

48. Prasad, V.M.; Miller, A.S.; Klose, T.; Sirohi, D.; Buda, G.; Jiang, W.; Kuhn, R.J.; Rossmann, M.G. Structure of the immature Zika virus at $9 \AA$ resolution. Nat. Struct. Mol. Biol. 2017, 24, 184-186. [CrossRef] [PubMed]

49. van Hemert, F.; Berkhout, B. Nucleotide composition of the Zika virus RNA genome and its codon usage. Virol. J. 2016, 13, 95. [CrossRef]

50. Zhu, Z.; Chan, J.F.; Tee, K.M.; Choi, G.K.; Lau, S.K.; Woo, P.C.; Tse, H.; Yuen, K.Y. Comparative genomic analysis of pre-epidemic and epidemic Zika virus strains for virological factors potentially associated with the rapidly expanding epidemic. Emerg. Microbes Infect. 2016, 5, e22. [CrossRef]

51. Coutard, B.; Barral, K.; Lichière, J.; Selisko, B.; Martin, B.; Aouadi, W.; Lombardia, M.O.; Debart, F.; Vasseur, J.J.; Guillemot, J.C.; et al. Zika Virus Methyltransferase: Structure and Functions for Drug Design Perspectives. J. Virol. 2017, 91. [CrossRef] [PubMed]

52. Kuno, G.; Chang, G.J. Full-length sequencing and genomic characterization of Bagaza, Kedougou, and Zika viruses. Arch. Virol. 2007, 152, 687-696. [CrossRef] [PubMed]

53. Baronti, C.; Piorkowski, G.; Charrel, R.N.; Boubis, L.; Leparc-Goffart, I.; de Lamballerie, X. Complete coding sequence of zika virus from a French polynesia outbreak in 2013. Genome Announc. 2014, 2. [CrossRef] [PubMed]

54. Piorkowski, G.; Richard, P.; Baronti, C.; Gallian, P.; Charrel, R.; Leparc-Goffart, I.; de Lamballerie, X. Complete coding sequence of Zika virus from Martinique outbreak in 2015. New Microbes New Infect. 2016, 11, 52-53. [CrossRef] [PubMed]

55. Dai, L.; Song, J.; Lu, X.; Deng, Y.Q.; Musyoki, A.M.; Cheng, H.; Zhang, Y.; Yuan, Y.; Song, H.; Haywood, J.; et al. Structures of the Zika Virus Envelope Protein and Its Complex with a Flavivirus Broadly Protective Antibody. Cell Host Microbe 2016, 19, 696-704. [CrossRef] [PubMed]

56. Khongwichit, S.; Sornjai, W.; Jitobaom, K.; Greenwood, M.; Greenwood, M.P.; Hitakarun, A.; Wikan, N.; Murphy, D.; Smith, D.R. A functional interaction between GRP78 and Zika virus E protein. Sci. Rep. 2021, 11, 393. [CrossRef]

57. Tan, T.Y.; Fibriansah, G.; Kostyuchenko, V.A.; Ng, T.S.; Lim, X.X.; Zhang, S.; Lim, X.N.; Wang, J.; Shi, J.; Morais, M.C.; et al. Capsid protein structure in Zika virus reveals the flavivirus assembly process. Nat. Commun. 2020, 11, 895. [CrossRef] 
58. Xu, X.; Song, H.; Qi, J.; Liu, Y.; Wang, H.; Su, C.; Shi, Y.; Gao, G.F. Contribution of intertwined loop to membrane association revealed by Zika virus full-length NS1 structure. EMBO J. 2016, 35, 2170-2178. [CrossRef]

59. Avirutnan, P.; Fuchs, A.; Hauhart, R.E.; Somnuke, P.; Youn, S.; Diamond, M.S.; Atkinson, J.P. Antagonism of the complement component C4 by flavivirus nonstructural protein NS1. J. Exp. Med. 2010, 207, 793-806. [CrossRef]

60. Avirutnan, P.; Hauhart, R.E.; Somnuke, P.; Blom, A.M.; Diamond, M.S.; Atkinson, J.P. Binding of flavivirus nonstructural protein NS1 to C4b binding protein modulates complement activation. J. Immunol. 2011, 187, 424-433. [CrossRef]

61. Xia, H.; Luo, H.; Shan, C.; Muruato, A.E.; Nunes, B.; Medeiros, D.; Zou, J.; Xie, X.; Giraldo, M.I.; Vasconcelos, P.; et al. An evolutionary NS1 mutation enhances Zika virus evasion of host interferon induction. Nat. Commun. 2018, 9, 414. [CrossRef]

62. Song, H.; Qi, J.; Haywood, J.; Shi, Y.; Gao, G.F. Zika virus NS1 structure reveals diversity of electrostatic surfaces among flaviviruses. Nat. Struct. Mol. Biol. 2016, 23, 456-458. [CrossRef]

63. Zhang, X.; Xie, X.; Xia, H.; Zou, J.; Huang, L.; Popov, V.L.; Chen, X.; Shi, P.Y. Zika Virus NS2A-Mediated Virion Assembly. mBio 2019, 10. [CrossRef] [PubMed]

64. Zhang, X.; Xie, X.; Zou, J.; Xia, H.; Shan, C.; Chen, X.; Shi, P.Y. Genetic and biochemical characterizations of Zika virus NS2A protein. Emerg. Microbes Infect. 2019, 8, 585-602. [CrossRef] [PubMed]

65. Phoo, W.W.; Li, Y.; Zhang, Z.; Lee, M.Y.; Loh, Y.R.; Tan, Y.B.; Ng, E.Y.; Lescar, J.; Kang, C.; Luo, D. Structure of the NS2B-NS3 protease from Zika virus after self-cleavage. Nat. Commun. 2016, 7, 13410. [CrossRef] [PubMed]

66. Xu, S.; Ci, Y.; Wang, L.; Yang, Y.; Zhang, L.; Xu, C.; Qin, C.; Shi, L. Zika virus NS3 is a canonical RNA helicase stimulated by NS5 RNA polymerase. Nucleic Acids Res. 2019, 47, 8693-8707. [CrossRef] [PubMed]

67. Giri, R.; Kumar, D.; Sharma, N.; Uversky, V.N. Intrinsically Disordered Side of the Zika Virus Proteome. Front. Cell Infect. Microbiol. 2016, 6, 144. [CrossRef]

68. Grant, A.; Ponia, S.S.; Tripathi, S.; Balasubramaniam, V.; Miorin, L.; Sourisseau, M.; Schwarz, M.C.; Sánchez-Seco, M.P.; Evans, M.J.; Best, S.M.; et al. Zika Virus Targets Human STAT2 to Inhibit Type I Interferon Signaling. Cell Host Microbe 2016, 19, 882-890. [CrossRef] [PubMed]

69. Zhao, B.; Yi, G.; Du, F.; Chuang, Y.C.; Vaughan, R.C.; Sankaran, B.; Kao, C.C.; Li, P. Structure and function of the Zika virus full-length NS5 protein. Nat. Commun. 2017, 8, 14762. [CrossRef] [PubMed]

70. Ferrero, D.S.; Ruiz-Arroyo, V.M.; Soler, N.; Usón, I.; Guarné, A.; Verdaguer, N. Supramolecular arrangement of the full-length Zika virus NS5. PLoS Pathog. 2019, 15, e1007656. [CrossRef]

71. Hamel, R.; Dejarnac, O.; Wichit, S.; Ekchariyawat, P.; Neyret, A.; Luplertlop, N.; Perera-Lecoin, M.; Surasombatpattana, P.; Talignani, L.; Thomas, F.; et al. Biology of Zika Virus Infection in Human Skin Cells. J. Virol. 2015, 89, 8880-8896. [CrossRef] [PubMed]

72. Vazquez, C.; Jurado, K.A. Playing Favorites: Integrin $\alpha \mathrm{v} \beta 5$ Mediates Preferential Zika Infection of Neural Stem Cells. Cell Stem Cell 2020, 26, 133-135. [CrossRef] [PubMed]

73. Srivastava, M.; Zhang, Y.; Chen, J.; Sirohi, D.; Miller, A.; Chen, Z.; Lu, H.; Xu, J.; Kuhn, R.J.; Andy Tao, W. Chemical proteomics tracks virus entry and uncovers NCAM1 as Zika virus receptor. Nat. Commun. 2020, 11, 3896. [CrossRef] [PubMed]

74. Persaud, M.; Martinez-Lopez, A.; Buffone, C.; Porcelli, S.A.; Diaz-Griffero, F. Infection by Zika viruses requires the transmembrane protein AXL, endocytosis and low pH. Virology 2018, 518, 301-312. [CrossRef]

75. Li, M.; Zhang, D.; Li, C.; Zheng, Z.; Fu, M.; Ni, F.; Liu, Y.; Du, T.; Wang, H.; Griffin, G.E.; et al. Characterization of Zika Virus Endocytic Pathways in Human Glioblastoma Cells. Front. Microbiol. 2020, 11, 242. [CrossRef] [PubMed]

76. Assenberg, R.; Mastrangelo, E.; Walter, T.S.; Verma, A.; Milani, M.; Owens, R.J.; Stuart, D.I.; Grimes, J.M.; Mancini, E.J. Crystal structure of a novel conformational state of the flavivirus NS3 protein: Implications for polyprotein processing and viral replication. J. Virol. 2009, 83, 12895-12906. [CrossRef] [PubMed]

77. Aktepe, T.E.; Liebscher, S.; Prier, J.E.; Simmons, C.P.; Mackenzie, J.M. The Host Protein Reticulon 3.1A Is Utilized by Flaviviruses to Facilitate Membrane Remodelling. Cell Rep. 2017, 21, 1639-1654. [CrossRef] [PubMed]

78. Cortese, M.; Goellner, S.; Acosta, E.G.; Neufeldt, C.J.; Oleksiuk, O.; Lampe, M.; Haselmann, U.; Funaya, C.; Schieber, N.; Ronchi, P.; et al. Ultrastructural Characterization of Zika Virus Replication Factories. Cell Rep. 2017, 18, 2113-2123. [CrossRef]

79. Ci, Y.; Liu, Z.Y.; Zhang, N.N.; Niu, Y.; Yang, Y.; Xu, C.; Yang, W.; Qin, C.F.; Shi, L. Zika NS1-induced ER remodeling is essential for viral replication. J. Cell Biol. 2020, 219. [CrossRef]

80. Owczarek, K.; Chykunova, Y.; Jassoy, C.; Maksym, B.; Rajfur, Z.; Pyrc, K. Zika virus: Mapping and reprogramming the entry. Cell Commun. Signal. 2019, 17, 41. [CrossRef]

81. Rossignol, E.D.; Peters, K.N.; Connor, J.H.; Bullitt, E. Zika virus induced cellular remodelling. Cell. Microbiol. 2017, 19. [CrossRef] [PubMed]

82. Caldas, L.A.; Azevedo, R.C.; da Silva, J.L.; de Souza, W. Microscopy analysis of Zika virus morphogenesis in mammalian cells. Sci. Rep. 2020, 10, 8370. [CrossRef]

83. Lumsden, W.H. An epidemic of virus disease in Southern Province, Tanganyika Territory, in 1952-53. II. General description and epidemiology. Trans. R. Soc. Trop. Med. Hyg. 1955, 49, 33-57. [CrossRef]

84. Boorman, J.P.; Draper, C.C. Isolations of arboviruses in the Lagos area of Nigeria, and a survey of antibodies to them in man and animals. Trans. R. Soc. Trop. Med. Hyg. 1968, 62, 269-277. [CrossRef]

85. Filipe, A.F.; Pinto, M.R. Arbovirus studies in Luanda, Angola. 2. Virological and serological studies during an outbreak of dengue-like disease caused by the Chikungunya virus. Bull. World Health Organ. 1973, 49, 37-40. [PubMed] 
86. Saluzzo, J.F.; Gonzalez, J.P.; Hervé, J.P.; Georges, A.J. [Epidemiological study of arboviruses in the Central African Republic: Demonstration of Chikungunya virus during 1978 and 1979]. Bull. Soc. Pathol. Exot. Fil. 1980, 73, 390-399.

87. Nimmannitya, S.; Halstead, S.B.; Cohen, S.N.; Margiotta, M.R. Dengue and chikungunya virus infection in man in Thailand, 1962-1964. I. Observations on hospitalized patients with hemorrhagic fever. Am. J. Trop. Med. Hyg. 1969, 18, 954-971. [CrossRef] [PubMed]

88. Hammon, W.M.; Rudnick, A.; Sather, G.E. Viruses associated with epidemic hemorrhagic fevers of the Philippines and Thailand. Science 1960, 131, 1102-1103. [CrossRef]

89. Carey, D.E.; Myers, R.M.; DeRanitz, C.M.; Jadhav, M.; Reuben, R. The 1964 chikungunya epidemic at Vellore, South India, including observations on concurrent dengue. Trans. R. Soc. Trop. Med. Hyg. 1969, 63, 434-445. [CrossRef]

90. Darwish, M.A.; Hoogstraal, H.; Roberts, T.J.; Ahmed, I.P.; Omar, F. A sero-epidemiological survey for certain arboviruses (Togaviridae) in Pakistan. Trans. R. Soc. Trop. Med. Hyg. 1983, 77, 442-445. [CrossRef]

91. Sergon, K.; Njuguna, C.; Kalani, R.; Ofula, V.; Onyango, C.; Konongoi, L.S.; Bedno, S.; Burke, H.; Dumilla, A.M.; Konde, J.; et al. Seroprevalence of Chikungunya virus (CHIKV) infection on Lamu Island, Kenya, October 2004. Am. J. Trop. Med. Hyg. 2008, 78, 333-337. [CrossRef]

92. Sergon, K.; Yahaya, A.A.; Brown, J.; Bedja, S.A.; Mlindasse, M.; Agata, N.; Allaranger, Y.; Ball, M.D.; Powers, A.M.; Ofula, V.; et al. Seroprevalence of Chikungunya virus infection on Grande Comore Island, union of the Comoros, 2005. Am. J. Trop. Med. Hyg. 2007, 76, 1189-1193. [CrossRef]

93. Beesoon, S.; Funkhouser, E.; Kotea, N.; Spielman, A.; Robich, R.M. Chikungunya fever, Mauritius, 2006. Emerg. Infect. Dis. 2008, 14, 337-338. [CrossRef] [PubMed]

94. Josseran, L.; Paquet, C.; Zehgnoun, A.; Caillere, N.; Le Tertre, A.; Solet, J.L.; Ledrans, M. Chikungunya disease outbreak, Reunion Island. Emerg. Infect. Dis. 2006, 12, 1994-1995. [CrossRef] [PubMed]

95. Yergolkar, P.N.; Tandale, B.V.; Arankalle, V.A.; Sathe, P.S.; Sudeep, A.B.; Gandhe, S.S.; Gokhle, M.D.; Jacob, G.P.; Hundekar, S.L.; Mishra, A.C. Chikungunya outbreaks caused by African genotype, India. Emerg. Infect. Dis. 2006, 12, 1580-1583. [CrossRef]

96. Ravi, V. Re-emergence of chikungunya virus in India. Indian J. Med. Microbiol. 2006, 24, 83-84. [CrossRef]

97. Ngwe Tun, M.M.; Inoue, S.; Thant, K.Z.; Talemaitoga, N.; Aryati, A.; Dimaano, E.M.; Matias, R.R.; Buerano, C.C.; Natividad, F.F.; Abeyewickreme, W.; et al. Retrospective seroepidemiological study of chikungunya infection in South Asia, Southeast Asia and the Pacific region. Epidemiol. Infect. 2016, 144, 2268-2275. [CrossRef]

98. Chusri, S.; Siripaitoon, P.; Silpapojakul, K.; Hortiwakul, T.; Charernmak, B.; Chinnawirotpisan, P.; Nisalak, A.; Thaisomboonsuk, B.; Klungthong, C.; Gibbons, R.V.; et al. Kinetics of chikungunya infections during an outbreak in Southern Thailand, 2008-2009. Am. J. Trop. Med. Hyg. 2014, 90, 410-417. [CrossRef] [PubMed]

99. Rezza, G.; Nicoletti, L.; Angelini, R.; Romi, R.; Finarelli, A.C.; Panning, M.; Cordioli, P.; Fortuna, C.; Boros, S.; Magurano, F.; et al. Infection with chikungunya virus in Italy: An outbreak in a temperate region. Lancet 2007, 370, 1840-1846. [CrossRef]

100. Gould, E.A.; Gallian, P.; De Lamballerie, X.; Charrel, R.N. First cases of autochthonous dengue fever and chikungunya fever in France: From bad dream to reality! Clin. Microbiol. Infect. 2010, 16, 1702-1704. [CrossRef]

101. D’Ortenzio, E.; Grandadam, M.; Balleydier, E.; Jaffar-Bandjee, M.C.; Michault, A.; Brottet, E.; Baville, M.; Filleul, L. A226V strains of Chikungunya virus, Réunion Island, 2010. Emerg. Infect. Dis. 2011, 17, 309-311. [CrossRef]

102. Wu, D.; Wu, J.; Zhang, Q.; Zhong, H.; Ke, C.; Deng, X.; Guan, D.; Li, H.; Zhang, Y.; Zhou, H.; et al. Chikungunya outbreak in Guangdong Province, China, 2010. Emerg. Infect. Dis. 2012, 18, 493-495. [CrossRef]

103. Ramachandran, V.G.; Das, S.; Roy, P.; Hada, V.; Mogha, N.S. Chikungunya: A reemerging infection spreading during 2010 dengue fever outbreak in National Capital Region of India. Virusdisease 2016, 27, 183-186. [CrossRef] [PubMed]

104. Cassadou, S.; Boucau, S.; Petit-Sinturel, M.; Huc, P.; Leparc-Goffart, I.; Ledrans, M. Emergence of chikungunya fever on the French side of Saint Martin island, October to December 2013. Euro Surveill. 2014, 19. [CrossRef]

105. Pan American Health Organization/World Health Organization. Number of Reported Cases of Chikungunya Fever in the Americas, by Country or Territory 2013-2014. Available online: https://www.paho.org/hq/dmdocuments/2015/2015-may-15 -cha-CHIKV-cumulative-cases.pdf (accessed on 11 February 2021).

106. Pan American Health Organization; World Health Organization. Epidemic Diseases-Chikungunya in the Americas. Available online: https://ais.paho.org/phip/viz/ed_chikungunya_amro.asp (accessed on 11 February 2021).

107. Dick, G.W.; Kitchen, S.F.; Haddow, A.J. Zika virus. I. Isolations and serological specificity. Trans. R. Soc. Trop. Med. Hyg. 1952, 46, 509-520. [CrossRef]

108. Smithburn, K.C. Neutralizing antibodies against certain recently isolated viruses in the sera of human beings residing in East Africa. J. Immunol. 1952, 69, 223-234.

109. Macnamara, F.N. Zika virus: A report on three cases of human infection during an epidemic of jaundice in Nigeria. Trans. R. Soc. Trop. Med. Hyg. 1954, 48, 139-145. [CrossRef]

110. Smithburn, K.C.; Taylor, R.M.; Rizk, F.; Kader, A. Immunity to certain arthropod-borne viruses among indigenous residents of Egypt. Am. J. Trop. Med. Hyg. 1954, 3, 9-18. [CrossRef] [PubMed]

111. Simpson, D.I. Zika Virus Infection in Man. Trans. R. Soc. Trop. Med. Hyg. 1964, 58, 335-338. [CrossRef]

112. Robin, Y.; Mouchet, J. Serological and entomological study on yellow fever in Sierra Leone. Bull. Soc. Pathol. Exot. Fil. 1975, 68, 249-258. 
113. Jan, C.; Languillat, G.; Renaudet, J.; Robin, Y. [A serological survey of arboviruses in Gabon]. Bull. Soc. Pathol. Exot. Fil. 1978, 71, 140-146.

114. Monlun, E.; Zeller, H.; Le Guenno, B.; Traoré-Lamizana, M.; Hervy, J.P.; Adam, F.; Ferrara, L.; Fontenille, D.; Sylla, R.; Mondo, M. [Surveillance of the circulation of arbovirus of medical interest in the region of eastern Senegal]. Bull. Soc. Pathol. Exot. Fil. 1993, $86,21-28$.

115. Smithburn, K.C.; Kerr, J.A.; Gatne, P.B. Neutralizing antibodies against certain viruses in the sera of residents of India. J. Immunol. 1954, 72, 248-257. [PubMed]

116. Olson, J.G.; Ksiazek, T.G.; Suhandiman; Triwibowo. Zika virus, a cause of fever in Central Java, Indonesia. Trans. R. Soc. Trop. Med. Hyg. 1981, 75, 389-393. [CrossRef]

117. Smithburn, K.C. Neutralizing antibodies against arthropod-borne viruses in the sera of long-time residents of Malaya and Borneo. Am. J. Hyg. 1954, 59, 157-163. [CrossRef]

118. Pond, W.L. Arthropod-borne virus antibodies in sera from residents of South-East Asia. Trans. R. Soc. Trop. Med. Hyg. 1963, 57, 364-371. [CrossRef]

119. Duffy, M.R.; Chen, T.H.; Hancock, W.T.; Powers, A.M.; Kool, J.L.; Lanciotti, R.S.; Pretrick, M.; Marfel, M.; Holzbauer, S.; Dubray, C.; et al. Zika virus outbreak on Yap Island, Federated States of Micronesia. N. Engl. J. Med. 2009, 360, 2536-2543. [CrossRef] [PubMed]

120. Cao-Lormeau, V.M.; Roche, C.; Teissier, A.; Robin, E.; Berry, A.L.; Mallet, H.P.; Sall, A.A.; Musso, D. Zika virus, French polynesia, South pacific, 2013. Emerg. Infect. Dis. 2014, 20, 1085-1086. [CrossRef]

121. Dupont-Rouzeyrol, M.; O'Connor, O.; Calvez, E.; Daurès, M.; John, M.; Grangeon, J.P.; Gourinat, A.C. Co-infection with Zika and dengue viruses in 2 patients, New Caledonia, 2014. Emerg. Infect. Dis. 2015, 21, 381-382. [CrossRef]

122. Musso, D.; Nilles, E.J.; Cao-Lormeau, V.M. Rapid spread of emerging Zika virus in the Pacific area. Clin. Microbiol. Infect. 2014, 20, O595-O596. [CrossRef]

123. Tognarelli, J.; Ulloa, S.; Villagra, E.; Lagos, J.; Aguayo, C.; Fasce, R.; Parra, B.; Mora, J.; Becerra, N.; Lagos, N.; et al. A report on the outbreak of Zika virus on Easter Island, South Pacific, 2014. Arch. Virol. 2016, 161, 665-668. [CrossRef] [PubMed]

124. Campos, G.S.; Bandeira, A.C.; Sardi, S.I. Zika Virus Outbreak, Bahia, Brazil. Emerg. Infect. Dis. 2015, 21, 1885-1886. [CrossRef] [PubMed]

125. Pan American Health Organization; World Health Organization. Cases of Zika Virus Disease, by Country or Territoriy. Available online: https:/ / www.paho.org/data/index.php/en/?option=com_content\&view=article\&id=524:zika-weekly-en\&Itemid=352 (accessed on 11 February 2021).

126. Center of Disease Control and Prevention. Zika Travel Information. Available online: https://wwwnc.cdc.gov/travel/page/ zika-information (accessed on 11 February 2021).

127. Center of Disease Control and Prevention. Geographic Distribution. Available online: https://www.cdc.gov/chikungunya/geo/ index.html (accessed on 11 February 2021).

128. Marchette, N.J.; Garcia, R.; Rudnick, A. Isolation of Zika virus from Aedes aegypti mosquitoes in Malaysia. Am. J. Trop. Med. Hyg. 1969, 18, 411-415. [CrossRef]

129. Guerbois, M.; Fernandez-Salas, I.; Azar, S.R.; Danis-Lozano, R.; Alpuche-Aranda, C.M.; Leal, G.; Garcia-Malo, I.R.; Diaz-Gonzalez, E.E.; Casas-Martinez, M.; Rossi, S.L.; et al. Outbreak of Zika Virus Infection, Chiapas State, Mexico, 2015, and First Confirmed Transmission by Aedes aegypti Mosquitoes in the Americas. J. Infect. Dis. 2016, 214, 1349-1356. [CrossRef] [PubMed]

130. Grard, G.; Caron, M.; Mombo, I.M.; Nkoghe, D.; Mboui Ondo, S.; Jiolle, D.; Fontenille, D.; Paupy, C.; Leroy, E.M. Zika virus in Gabon (Central Africa)-2007: A new threat from Aedes albopictus? PLoS Negl. Trop. Dis. 2014, 8, e2681. [CrossRef]

131. Wong, P.S.; Li, M.Z.; Chong, C.S.; Ng, L.C.; Tan, C.H. Aedes (Stegomyia) albopictus (Skuse): A potential vector of Zika virus in Singapore. PLoS Negl. Trop. Dis. 2013, 7, e2348. [CrossRef]

132. Honório, N.A.; Wiggins, K.; Câmara, D.C.P.; Eastmond, B.; Alto, B.W. Chikungunya virus vector competency of Brazilian and Florida mosquito vectors. PLoS Negl. Trop. Dis. 2018, 12, e0006521. [CrossRef]

133. Vega-Rúa, A.; Zouache, K.; Girod, R.; Failloux, A.B.; Lourenço-de-Oliveira, R. High level of vector competence of Aedes aegypti and Aedes albopictus from ten American countries as a crucial factor in the spread of Chikungunya virus. J. Virol. 2014, 88, 6294-6306. [CrossRef]

134. Vazeille, M.; Moutailler, S.; Coudrier, D.; Rousseaux, C.; Khun, H.; Huerre, M.; Thiria, J.; Dehecq, J.S.; Fontenille, D.; Schuffenecker, I.; et al. Two Chikungunya isolates from the outbreak of La Reunion (Indian Ocean) exhibit different patterns of infection in the mosquito, Aedes albopictus. PLoS ONE 2007, 2, e1168. [CrossRef]

135. Tsetsarkin, K.A.; Vanlandingham, D.L.; McGee, C.E.; Higgs, S. A single mutation in chikungunya virus affects vector specificity and epidemic potential. PLoS Pathog. 2007, 3, e201. [CrossRef]

136. Pan American Health Organization; World Health Organization. Report Case of Dengue Fever in The Americas. Available online: https://www.paho.org/data/index.php/en/mnu-topics/indicadores-dengue-en/dengue-nacional-en/252-denguepais-ano-en.html (accessed on 20 February 2021).

137. Ball, J.D.; Elbadry, M.A.; Telisma, T.; White, S.K.; Chavannes, S.; Anilis, M.G.; Prosperi, M.; Cummings, D.A.T.; Lednicky, J.A.; Morris, J.G.; et al. Clinical and Epidemiologic Patterns of Chikungunya Virus Infection and Coincident Arboviral Disease in a School Cohort in Haiti, 2014-2015. Clin. Infect. Dis. 2019, 68, 919-926. [CrossRef] 
138. Méndez, J.A.; Usme-Ciro, J.A.; Domingo, C.; Rey, G.J.; Sánchez, J.A.; Tenorio, A.; Gallego-Gomez, J.C. Phylogenetic reconstruction of dengue virus type 2 in Colombia. Virol. J. 2012, 9, 64. [CrossRef]

139. Mattar, S.; Miranda, J.; Pinzon, H.; Tique, V.; Bolanos, A.; Aponte, J.; Arrieta, G.; Gonzalez, M.; Barrios, K.; Contreras, H.; et al. Outbreak of Chikungunya virus in the north Caribbean area of Colombia: Clinical presentation and phylogenetic analysis. $J$. Infect. Dev. Ctries 2015, 9, 1126-1132. [CrossRef]

140. Oviedo-Pastrana, M.; Méndez, N.; Mattar, S.; Arrieta, G.; Gomezcaceres, L. Epidemic outbreak of Chikungunya in two neighboring towns in the Colombian Caribbean: A survival analysis. Arch. Public Health 2017, 75, 1. [CrossRef]

141. Pacheco, O.; Beltrán, M.; Nelson, C.A.; Valencia, D.; Tolosa, N.; Farr, S.L.; Padilla, A.V.; Tong, V.T.; Cuevas, E.L.; Espinosa-Bode, A.; et al. Zika Virus Disease in Colombia-Preliminary Report. N. Engl. J. Med. 2016. [CrossRef] [PubMed]

142. Carrillo-Hernández, M.Y.; Ruiz-Saenz, J.; Villamizar, L.J.; Gómez-Rangel, S.Y.; Martínez-Gutierrez, M. Co-circulation and simultaneous co-infection of dengue, chikungunya, and zika viruses in patients with febrile syndrome at the ColombianVenezuelan border. BMC Infect. Dis. 2018, 18, 61. [CrossRef]

143. Mercado-Reyes, M.; Acosta-Reyes, J.; Navarro-Lechuga, E.; Corchuelo, S.; Rico, A.; Parra, E.; Tolosa, N.; Pardo, L.; González, M.; Martìn-Rodriguez-Hernández, J.; et al. Dengue, chikungunya and zika virus coinfection: Results of the national surveillance during the zika epidemic in Colombia. Epidemiol. Infect. 2019, 147, e77. [CrossRef] [PubMed]

144. Villamil-Gómez, W.E.; González-Camargo, O.; Rodriguez-Ayubi, J.; Zapata-Serpa, D.; Rodriguez-Morales, A.J. Dengue, chikungunya and Zika co-infection in a patient from Colombia. J. Infect. Public Health 2016, 9, 684-686. [CrossRef]

145. Villamil-Gómez, W.E.; Rodríguez-Morales, A.J.; Uribe-García, A.M.; González-Arismendy, E.; Castellanos, J.E.; Calvo, E.P.; Álvarez-Mon, M.; Musso, D. Zika, dengue, and chikungunya co-infection in a pregnant woman from Colombia. Int. J. Infect. Dis. 2016, 51, 135-138. [CrossRef] [PubMed]

146. Gunturiz, M.L.; Cortés, L.; Cuevas, E.L.; Chaparro, P.; Ospina, M.L. Congenital cerebral toxoplasmosis, Zika and chikungunya virus infections: A case report. Biomedica 2018, 38, 144-152. [CrossRef] [PubMed]

147. Cherabuddi, K.; Iovine, N.M.; Shah, K.; White, S.K.; Paisie, T.; Salemi, M.; Morris, J.G.; Lednicky, J.A. Zika and Chikungunya virus co-infection in a traveller returning from Colombia, 2016: Virus isolation and genetic analysis. JMM Case Rep. 2016, 3, e005072. [CrossRef] [PubMed]

148. Nunes, M.R.; Faria, N.R.; de Vasconcelos, J.M.; Golding, N.; Kraemer, M.U.; de Oliveira, L.F.; Azevedo, R.o.S.; da Silva, D.E.; da Silva, E.V.; da Silva, S.P.; et al. Emergence and potential for spread of Chikungunya virus in Brazil. BMC Med. 2015, 13, 102. [CrossRef] [PubMed]

149. Magalhaes, T.; Braga, C.; Cordeiro, M.T.; Oliveira, A.L.S.; Castanha, P.M.S.; Maciel, A.P.R.; Amancio, N.M.L.; Gouveia, P.N.; Peixoto-da-Silva, V.J.; Peixoto, T.F.L.; et al. Zika virus displacement by a chikungunya outbreak in Recife, Brazil. PLoS Negl. Trop. Dis. 2017, 11, e0006055. [CrossRef] [PubMed]

150. Sardi, S.I.; Somasekar, S.; Naccache, S.N.; Bandeira, A.C.; Tauro, L.B.; Campos, G.S.; Chiu, C.Y. Coinfections of Zika and Chikungunya Viruses in Bahia, Brazil, Identified by Metagenomic Next-Generation Sequencing. J. Clin. Microbiol. 2016, 54, 2348-2353. [CrossRef] [PubMed]

151. Cabral-Castro, M.J.; Cavalcanti, M.G.; Peralta, R.H.S.; Peralta, J.M. Molecular and serological techniques to detect co-circulation of DENV, ZIKV and CHIKV in suspected dengue-like syndrome patients. J. Clin. Virol. 2016, 82, 108-111. [CrossRef] [PubMed]

152. Brasil, P.; Pereira, J.P.; Moreira, M.E.; Ribeiro Nogueira, R.M.; Damasceno, L.; Wakimoto, M.; Rabello, R.S.; Valderramos, S.G.; Halai, U.A.; Salles, T.S.; et al. Zika Virus Infection in Pregnant Women in Rio de Janeiro. N. Engl. J. Med. 2016, 375, $2321-2334$. [CrossRef]

153. Mehta, R.; Soares, C.N.; Medialdea-Carrera, R.; Ellul, M.; da Silva, M.T.T.; Rosala-Hallas, A.; Jardim, M.R.; Burnside, G.; Pamplona, L.; Bhojak, M.; et al. The spectrum of neurological disease associated with Zika and chikungunya viruses in adults in Rio de Janeiro, Brazil: A case series. PLoS Negl. Trop. Dis. 2018, 12, e0006212. [CrossRef]

154. Charlys da Costa, A.; Thézé, J.; Komninakis, S.C.V.; Sanz-Duro, R.L.; Felinto, M.R.L.; Moura, L.C.C.; Barroso, I.M.O.; Santos, L.E.C.; Nunes, M.A.L.; Moura, A.A.; et al. Spread of Chikungunya Virus East/Central/South African Genotype in Northeast Brazil. Emerg. Infect. Dis. 2017, 23, 1742-1744. [CrossRef]

155. Brito, C.A.A.; Azevedo, F.; Cordeiro, M.T.; Marques, E.T.A.; Franca, R.F.O. Central and peripheral nervous system involvement caused by Zika and chikungunya coinfection. PLoS Negl. Trop. Dis. 2017, 11, e0005583. [CrossRef] [PubMed]

156. Prata-Barbosa, A.; Cleto-Yamane, T.L.; Robaina, J.R.; Guastavino, A.B.; de Magalhães-Barbosa, M.C.; Brindeiro, R.M.; Medronho, R.A.; da Cunha, A.J.L.A. Co-infection with Zika and Chikungunya viruses associated with fetal death-A case report. Int. J. Infect. Dis. 2018, 72, 25-27. [CrossRef]

157. Bagno, F.F.; Figueiredo, M.M.; Villarreal, J.; Pereira, G.C.; Godoi, L.C.; da Fonseca, F.G. Undetected Chikungunya virus coinfections in a Brazilian region presenting hyper-endemic circulation of Dengue and Zika. J. Clin. Virol. 2019, 113, 27-30. [CrossRef]

158. Balmaseda, A.; Gordon, A.; Gresh, L.; Ojeda, S.; Saborio, S.; Tellez, Y.; Sanchez, N.; Kuan, G.; Harris, E. Clinical Attack Rate of Chikungunya in a Cohort of Nicaraguan Children. Am. J. Trop. Med. Hyg. 2016, 94, 397-399. [CrossRef]

159. Waggoner, J.J.; Gresh, L.; Mohamed-Hadley, A.; Ballesteros, G.; Davila, M.J.; Tellez, Y.; Sahoo, M.K.; Balmaseda, A.; Harris, E.; Pinsky, B.A. Single-Reaction Multiplex Reverse Transcription PCR for Detection of Zika, Chikungunya, and Dengue Viruses. Emerg. Infect. Dis. 2016, 22, 1295-1297. [CrossRef] [PubMed] 
160. Waggoner, J.J.; Gresh, L.; Vargas, M.J.; Ballesteros, G.; Tellez, Y.; Soda, K.J.; Sahoo, M.K.; Nuñez, A.; Balmaseda, A.; Harris, E.; et al. Viremia and Clinical Presentation in Nicaraguan Patients Infected With Zika Virus, Chikungunya Virus, and Dengue Virus. Clin. Infect. Dis. 2016, 63, 1584-1590. [CrossRef] [PubMed]

161. Centers for Disease Control (CDC). Dengue epidemic-Ecuador, 1988. MMWR Morb. Mortal. Wkly. Rep. 1989, 38, $419-421$.

162. Pan American Health Organization; World Health Organization. Chikungunya: Data, Maps and Statistics. Available online: https: / / www.paho.org/hq/index.php?option=com_topics\&view=rdmore\&cid=5927\&Itemid=40931 \$ langle $\$=$ en (accessed on 20 February 2021).

163. Pan American Health Organization; World Health Organization. Zika-Epidemiological Report. Available online: https://www. paho.org/hq/dmdocuments/2017/2017-phe-zika-situation-report-ecu.pdf (accessed on 20 February 2021).

164. Zambrano, H.; Waggoner, J.J.; Almeida, C.; Rivera, L.; Benjamin, J.Q.; Pinsky, B.A. Zika Virus and Chikungunya Virus CoInfections: A Series of Three Cases from a Single Center in Ecuador. Am. J. Trop. Med. Hyg. 2016, 95, 894-896. [CrossRef] [PubMed]

165. Acevedo, N.; Waggoner, J.; Rodriguez, M.; Rivera, L.; Landivar, J.; Pinsky, B.; Zambrano, H. Zika Virus, Chikungunya Virus, and Dengue Virus in Cerebrospinal Fluid from Adults with Neurological Manifestations, Guayaquil, Ecuador. Front. Microbiol. 2017, 8, 42. [CrossRef]

166. Dantes, H.G.; Koopman, J.S.; Addy, C.L.; Zarate, M.L.; Marin, M.A.; Longini Júnior, I.M.; Guttierez, E.S.; Rodriguez, V.A.; Garcia, L.G.; Mirelles, E.R. Dengue epidemics on the Pacific Coast of Mexico. Int. J. Epidemiol. 1988, 17, 178-186. [CrossRef] [PubMed]

167. Díaz-Quiñonez, J.A.; Ortiz-Alcántara, J.; Fragoso-Fonseca, D.E.; Garcés-Ayala, F.; Escobar-Escamilla, N.; Vázquez-Pichardo, M.; Núñez-León, A.; Torres-Rodríguez, M.e.L.; Torres-Longoria, B.; López-Martínez, I.; et al. Complete genome sequences of chikungunya virus strains isolated in Mexico: First detection of imported and autochthonous cases. Genome Announc. 2015, 3. [CrossRef]

168. Jimenez Corona, M.E.; De la Garza Barroso, A.L.; Rodriguez Martínez, J.C.; Luna Guzmán, N.I.; Ruiz Matus, C.; Díaz Quiñonez, J.A.; Lopez Martinez, I.; Kuri Morales, P.A. Clinical and Epidemiological Characterization of Laboratory-Confirmed Autochthonous Cases of Zika Virus Disease in Mexico. PLoS Curr. 2016, 8. [CrossRef]

169. Pan American Health Organization; World Health Organization. Cases of Chikungunya Virus Disease. Available online: https://www.paho.org/data/index.php/en/mnu-topics/chikv-en/550-chikv-weekly-en.html (accessed on 20 February 2021)

170. Eligio-García, L.; Crisóstomo-Vázquez, M.D.P.; Caballero-García, M.L.; Soria-Guerrero, M.; Méndez-Galván, J.F.; López-Cancino, S.A.; Jiménez-Cardoso, E. Co-infection of Dengue, Zika and Chikungunya in a group of pregnant women from Tuxtla Gutiérrez, Chiapas: Preliminary data. 2019. PLoS Negl. Trop. Dis. 2020, 14, e0008880. [CrossRef]

171. Chaaithanya, I.K.; Muruganandam, N.; Surya, P.; Anwesh, M.; Alagarasu, K.; Vijayachari, P. Association of Oligoadenylate Synthetase Gene Cluster and DC-SIGN (CD209) Gene Polymorphisms with Clinical Symptoms in Chikungunya Virus Infection. DNA Cell Biol. 2016, 35, 44-50. [CrossRef] [PubMed]

172. Tassaneetrithep, B.; Burgess, T.H.; Granelli-Piperno, A.; Trumpfheller, C.; Finke, J.; Sun, W.; Eller, M.A.; Pattanapanyasat, K.; Sarasombath, S.; Birx, D.L.; et al. DC-SIGN (CD209) mediates dengue virus infection of human dendritic cells. J. Exp. Med. 2003, 197, 823-829. [CrossRef] [PubMed]

173. Shimojima, M.; Takenouchi, A.; Shimoda, H.; Kimura, N.; Maeda, K. Distinct usage of three C-type lectins by Japanese encephalitis virus: DC-SIGN, DC-SIGNR, and LSECtin. Arch. Virol. 2014, 159, 2023-2031. [CrossRef]

174. Cormier, E.G.; Durso, R.J.; Tsamis, F.; Boussemart, L.; Manix, C.; Olson, W.C.; Gardner, J.P.; Dragic, T. L-SIGN (CD209L) and DC-SIGN (CD209) mediate transinfection of liver cells by hepatitis C virus. Proc. Natl. Acad. Sci. USA 2004, 101, 14067-14072. [CrossRef]

175. Marzi, A.; Gramberg, T.; Simmons, G.; Möller, P.; Rennekamp, A.J.; Krumbiegel, M.; Geier, M.; Eisemann, J.; Turza, N.; Saunier, B.; et al. DC-SIGN and DC-SIGNR interact with the glycoprotein of Marburg virus and the S protein of severe acute respiratory syndrome coronavirus. J. Virol. 2004, 78, 12090-12095. [CrossRef]

176. Alvarez, C.P.; Lasala, F.; Carrillo, J.; Muñiz, O.; Corbí, A.L.; Delgado, R. C-type lectins DC-SIGN and L-SIGN mediate cellular entry by Ebola virus in cis and in trans. J. Virol. 2002, 76, 6841-6844. [CrossRef]

177. Hensler, H.R.; Tomaszewski, M.J.; Rappocciolo, G.; Rinaldo, C.R.; Jenkins, F.J. Human herpesvirus 8 glycoprotein B binds the entry receptor DC-SIGN. Virus Res. 2014, 190, 97-103. [CrossRef]

178. Londrigan, S.L.; Turville, S.G.; Tate, M.D.; Deng, Y.M.; Brooks, A.G.; Reading, P.C. N-linked glycosylation facilitates sialic acid-independent attachment and entry of influenza A viruses into cells expressing DC-SIGN or L-SIGN. J. Virol. 2011, 85, 2990-3000. [CrossRef]

179. Curtis, B.M.; Scharnowske, S.; Watson, A.J. Sequence and expression of a membrane-associated C-type lectin that exhibits CD4-independent binding of human immunodeficiency virus envelope glycoprotein gp120. Proc. Natl. Acad. Sci. USA 1992, 89, 8356-8360. [CrossRef] [PubMed]

180. Geijtenbeek, T.B.; van Duijnhoven, G.C.; van Vliet, S.J.; Krieger, E.; Vriend, G.; Figdor, C.G.; van Kooyk, Y. Identification of different binding sites in the dendritic cell-specific receptor DC-SIGN for intercellular adhesion molecule 3 and HIV-1. J. Biol. Chem. 2002, 277, 11314-11320. [CrossRef]

181. Jeffers, S.A.; Hemmila, E.M.; Holmes, K.V. Human coronavirus 229E can use CD209L (L-SIGN) to enter cells. Adv. Exp. Med. Biol. 2006, 581, 265-269. [CrossRef] [PubMed] 
182. Amraie, R.; Napoleon, M.A.; Yin, W.; Berrigan, J.; Suder, E.; Zhao, G.; Olejnik, J.; Gummuluru, S.; Muhlberger, E.; Chitalia, V.; et al. CD209L/L-SIGN and CD209/DC-SIGN act as receptors for SARS-CoV-2 and are differentially expressed in lung and kidney epithelial and endothelial cells. bioRxiv 2020. [CrossRef]

183. Yang, Z.Y.; Huang, Y.; Ganesh, L.; Leung, K.; Kong, W.P.; Schwartz, O.; Subbarao, K.; Nabel, G.J. pH-dependent entry of severe acute respiratory syndrome coronavirus is mediated by the spike glycoprotein and enhanced by dendritic cell transfer through DC-SIGN. J. Virol. 2004, 78, 5642-5650. [CrossRef] [PubMed]

184. Jeffers, S.A.; Tusell, S.M.; Gillim-Ross, L.; Hemmila, E.M.; Achenbach, J.E.; Babcock, G.J.; Thomas, W.D.; Thackray, L.B.; Young, M.D.; Mason, R.J.; et al. CD209L (L-SIGN) is a receptor for severe acute respiratory syndrome coronavirus. Proc. Natl. Acad. Sci. USA 2004, 101, 15748-15753. [CrossRef] [PubMed]

185. Bucardo, F.; Reyes, Y.; Morales, M.; Briceño, R.; González, F.; Lundkvist, Å.; Svensson, L.; Nordgren, J. Association of Genetic Polymorphisms in DC-SIGN, Toll-Like Receptor 3, and Tumor Necrosis Factor $\alpha$ Genes and the Lewis-Negative Phenotype With Chikungunya Infection and Disease in Nicaragua. J. Infect. Dis. 2021, 223, 278-286. [CrossRef]

186. Sakuntabhai, A.; Turbpaiboon, C.; Casadémont, I.; Chuansumrit, A.; Lowhnoo, T.; Kajaste-Rudnitski, A.; Kalayanarooj, S.M.; Tangnararatchakit, K.; Tangthawornchaikul, N.; Vasanawathana, S.; et al. A variant in the CD209 promoter is associated with severity of dengue disease. Nat. Genet. 2005, 37, 507-513. [CrossRef]

187. Navarro-Sanchez, E.; Altmeyer, R.; Amara, A.; Schwartz, O.; Fieschi, F.; Virelizier, J.L.; Arenzana-Seisdedos, F.; Desprès, P. Dendritic-cell-specific ICAM3-grabbing non-integrin is essential for the productive infection of human dendritic cells by mosquito-cell-derived dengue viruses. EMBO Rep. 2003, 4, 723-728. [CrossRef]

188. Barba-Spaeth, G.; Longman, R.S.; Albert, M.L.; Rice, C.M. Live attenuated yellow fever 17D infects human DCs and allows for presentation of endogenous and recombinant T cell epitopes. J. Exp. Med. 2005, 202, 1179-1184. [CrossRef] [PubMed]

189. Froelich, S.; Tai, A.; Kennedy, K.; Zubair, A.; Wang, P. Virus-receptor mediated transduction of dendritic cells by lentiviruses enveloped with glycoproteins derived from Semliki Forest virus. PLoS ONE 2011, 6, e21491. [CrossRef]

190. Long, K.M.; Whitmore, A.C.; Ferris, M.T.; Sempowski, G.D.; McGee, C.; Trollinger, B.; Gunn, B.; Heise, M.T. Dendritic cell immunoreceptor regulates Chikungunya virus pathogenesis in mice. J. Virol. 2013, 87, 5697-5706. [CrossRef]

191. Varga, N.; Sutkeviciute, I.; Ribeiro-Viana, R.; Berzi, A.; Ramdasi, R.; Daghetti, A.; Vettoretti, G.; Amara, A.; Clerici, M.; Rojo, J.; et al. A multivalent inhibitor of the DC-SIGN dependent uptake of HIV-1 and Dengue virus. Biomaterials 2014, 35, 4175-4184. [CrossRef]

192. Alen, M.M.; De Burghgraeve, T.; Kaptein, S.J.; Balzarini, J.; Neyts, J.; Schols, D. Broad antiviral activity of carbohydrate-binding agents against the four serotypes of dengue virus in monocyte-derived dendritic cells. PLoS ONE 2011, 6, e21658. [CrossRef] [PubMed]

193. Martínez, M.G.; Prado Acosta, M.; Candurra, N.A.; Ruzal, S.M. S-layer proteins of Lactobacillus acidophilus inhibits JUNV infection. Biochem. Biophys. Res. Commun. 2012, 422, 590-595. [CrossRef] [PubMed]

194. Gao, X.; Huang, L.; Zhu, L.; Mou, C.; Hou, Q.; Yu, Q. Inhibition of H9N2 Virus Invasion into Dendritic Cells by the S-Layer Protein from. Front. Cell Infect. Microbiol. 2016, 6, 137. [CrossRef] [PubMed]

195. Li, L.; Jose, J.; Xiang, Y.; Kuhn, R.J.; Rossmann, M.G. Structural changes of envelope proteins during alphavirus fusion. Nature 2010, 468, 705-708. [CrossRef] [PubMed]

196. Dudha, N.; Rana, J.; Rajasekharan, S.; Gabrani, R.; Gupta, A.; Chaudhary, V.K.; Gupta, S. Host-pathogen interactome analysis of Chikungunya virus envelope proteins E1 and E2. Virus Genes 2015, 50, 200-209. [CrossRef]

197. Akhrymuk, I.; Kulemzin, S.V.; Frolova, E.I. Evasion of the innate immune response: The Old World alphavirus nsP2 protein induces rapid degradation of Rpb1, a catalytic subunit of RNA polymerase II. J. Virol. 2012, 86, 7180-7191. [CrossRef] [PubMed]

198. Bouraï, M.; Lucas-Hourani, M.; Gad, H.H.; Drosten, C.; Jacob, Y.; Tafforeau, L.; Cassonnet, P.; Jones, L.M.; Judith, D.; Couderc, T.; et al. Mapping of Chikungunya virus interactions with host proteins identified nsP2 as a highly connected viral component. $J$. Virol. 2012, 86, 3121-3134. [CrossRef] [PubMed]

199. Rana, J.; Gulati, S.; Rajasekharan, S.; Gupta, A.; Chaudhary, V.; Gupta, S. Identification of potential molecular associations between chikungunya virus non-structural protein 2 and human host proteins. Acta Virol. 2017, 61, 39-47. [CrossRef]

200. Thaa, B.; Biasiotto, R.; Eng, K.; Neuvonen, M.; Götte, B.; Rheinemann, L.; Mutso, M.; Utt, A.; Varghese, F.; Balistreri, G.; et al. Differential Phosphatidylinositol-3-Kinase-Akt-mTOR Activation by Semliki Forest and Chikungunya Viruses Is Dependent on nsP3 and Connected to Replication Complex Internalization. J. Virol. 2015, 89, 11420-11437. [CrossRef] [PubMed]

201. Scholte, F.E.; Tas, A.; Albulescu, I.C.; Žusinaite, E.; Merits, A.; Snijder, E.J.; van Hemert, M.J. Stress granule components G3BP1 and G3BP2 play a proviral role early in Chikungunya virus replication. J. Virol. 2015, 89, 4457-4469. [CrossRef] [PubMed]

202. Reid, S.P.; Tritsch, S.R.; Kota, K.; Chiang, C.Y.; Dong, L.; Kenny, T.; Brueggemann, E.E.; Ward, M.D.; Cazares, L.H.; Bavari, S. Sphingosine kinase 2 is a chikungunya virus host factor co-localized with the viral replication complex. Emerg. Microbes Infect. 2015, 4, e61. [CrossRef] [PubMed]

203. Rathore, A.P.; Haystead, T.; Das, P.K.; Merits, A.; Ng, M.L.; Vasudevan, S.G. Chikungunya virus nsP3 \& nsP4 interacts with HSP-90 to promote virus replication: HSP-90 inhibitors reduce CHIKV infection and inflammation in vivo. Antivir. Res. 2014, 103, 7-16. [CrossRef] [PubMed]

204. Rathore, A.P.; Ng, M.L.; Vasudevan, S.G. Differential unfolded protein response during Chikungunya and Sindbis virus infection: CHIKV nsP4 suppresses eIF2 $\alpha$ phosphorylation. Virol. J. 2013, 10, 36. [CrossRef]

205. Shang, Z.; Song, H.; Shi, Y.; Qi, J.; Gao, G.F. Crystal Structure of the Capsid Protein from Zika Virus. J. Mol. Biol. 2018. [CrossRef] 
206. Hou, S.; Kumar, A.; Xu, Z.; Airo, A.M.; Stryapunina, I.; Wong, C.P.; Branton, W.; Tchesnokov, E.; Götte, M.; Power, C.; et al. Zika virus hijacks stress granule proteins and modulates the host stress response. J. Virol. 2017. [CrossRef]

207. Fontaine, K.A.; Leon, K.E.; Khalid, M.M.; Tomar, S.; Jimenez-Morales, D.; Dunlap, M.; Kaye, J.A.; Shah, P.S.; Finkbeiner, S.; Krogan, N.J.; et al. The Cellular NMD Pathway Restricts Zika Virus Infection and Is Targeted by the Viral Capsid Protein. mBio 2018, 9. [CrossRef]

208. Li, H.; Saucedo-Cuevas, L.; Yuan, L.; Ross, D.; Johansen, A.; Sands, D.; Stanley, V.; Guemez-Gamboa, A.; Gregor, A.; Evans, T.; et al. Zika Virus Protease Cleavage of Host Protein Septin-2 Mediates Mitotic Defects in Neural Progenitors. Neuron 2019, 101, 1089-1098.e1084. [CrossRef]

209. Hastings, A.K.; Yockey, L.J.; Jagger, B.W.; Hwang, J.; Uraki, R.; Gaitsch, H.F.; Parnell, L.A.; Cao, B.; Mysorekar, I.U.; Rothlin, C.V.; et al. TAM Receptors Are Not Required for Zika Virus Infection in Mice. Cell Rep. 2017, 19, 558-568. [CrossRef]

210. Laureti, M.; Narayanan, D.; Rodriguez-Andres, J.; Fazakerley, J.K.; Kedzierski, L. Flavivirus Receptors: Diversity, Identity, and Cell Entry. Front. Immunol. 2018, 9, 2180. [CrossRef] [PubMed]

211. Meertens, L.; Labeau, A.; Dejarnac, O.; Cipriani, S.; Sinigaglia, L.; Bonnet-Madin, L.; Le Charpentier, T.; Hafirassou, M.L.; Zamborlini, A.; Cao-Lormeau, V.M.; et al. Axl Mediates ZIKA Virus Entry in Human Glial Cells and Modulates Innate Immune Responses. Cell Rep. 2017, 18, 324-333. [CrossRef]

212. Pujhari, S.; Brustolin, M.; Macias, V.M.; Nissly, R.H.; Nomura, M.; Kuchipudi, S.V.; Rasgon, J.L. Heat shock protein 70 (Hsp70) mediates Zika virus entry, replication, and egress from host cells. Emerg. Microbes Infect. 2019, 8, 8-16. [CrossRef] [PubMed]

213. Tabata, T.; Petitt, M.; Puerta-Guardo, H.; Michlmayr, D.; Wang, C.; Fang-Hoover, J.; Harris, E.; Pereira, L. Zika Virus Targets Different Primary Human Placental Cells, Suggesting Two Routes for Vertical Transmission. Cell Host Microbe 2016, 20, 155-166. [CrossRef] [PubMed]

214. Strange, D.P.; Jiyarom, B.; Pourhabibi Zarandi, N.; Xie, X.; Baker, C.; Sadri-Ardekani, H.; Shi, P.Y.; Verma, S. Axl Promotes Zika Virus Entry and Modulates the Antiviral State of Human Sertoli Cells. mBio 2019, 10. [CrossRef]

215. Zhou, J.; Chi, X.; Cheng, M.; Huang, X.; Liu, X.; Fan, J.; Xu, H.; Lin, T.; Shi, L.; Qin, C.; et al. Zika virus degrades the $\omega-3$ fatty acid transporter Mfsd2a in brain microvascular endothelial cells and impairs lipid homeostasis. Sci. Adv. 2019, 5, eaax7142. [CrossRef]

216. Wu, Y.; Liu, Q.; Zhou, J.; Xie, W.; Chen, C.; Wang, Z.; Yang, H.; Cui, J. Zika virus evades interferon-mediated antiviral response through the co-operation of multiple nonstructural proteins in vitro. Cell Discov. 2017, 3, 17006. [CrossRef]

217. Ngueyen, T.T.N.; Kim, S.J.; Lee, J.Y.; Myoung, J. Zika Virus Proteins NS2A and NS4A Are Major Antagonists that Reduce IFN- $\beta$ Promoter Activity Induced by the MDA5/RIG-I Signaling Pathway. J. Microbiol. Biotechnol. 2019, 29, 1665-1674. [CrossRef]

218. Hu, Y.; Dong, X.; He, Z.; Wu, Y.; Zhang, S.; Lin, J.; Yang, Y.; Chen, J.; An, S.; Yin, Y.; et al. Zika virus antagonizes interferon response in patients and disrupts RIG-I-MAVS interaction through its CARD-TM domains. Cell Biosci. 2019, 9, 46. [CrossRef]

219. Ma, J.; Ketkar, H.; Geng, T.; Lo, E.; Wang, L.; Xi, J.; Sun, Q.; Zhu, Z.; Cui, Y.; Yang, L.; et al. Zika Virus Non-structural Protein 4A Blocks the RLR-MAVS Signaling. Front. Microbiol. 2018, 9, 1350. [CrossRef]

220. Chaudhary, V.; Yuen, K.S.; Chan, J.F.; Chan, C.P.; Wang, P.H.; Cai, J.P.; Zhang, S.; Liang, M.; Kok, K.H.; Yuen, K.Y.; et al. Selective Activation of Type II Interferon Signaling by Zika Virus NS5 Protein. J. Virol. 2017, 91. [CrossRef]

221. Kondratowicz, A.S.; Lennemann, N.J.; Sinn, P.L.; Davey, R.A.; Hunt, C.L.; Moller-Tank, S.; Meyerholz, D.K.; Rennert, P.; Mullins, R.F.; Brindley, M.; et al. T-cell immunoglobulin and mucin domain 1 (TIM-1) is a receptor for Zaire Ebolavirus and Lake Victoria Marburgvirus. Proc. Natl. Acad. Sci. USA 2011, 108, 8426-8431. [CrossRef]

222. Kuchroo, V.K.; Dardalhon, V.; Xiao, S.; Anderson, A.C. New roles for TIM family members in immune regulation. Nat. Rev. Immunol. 2008, 8, 577-580. [CrossRef]

223. Brunton, B.; Rogers, K.; Phillips, E.K.; Brouillette, R.B.; Bouls, R.; Butler, N.S.; Maury, W. TIM-1 serves as a receptor for Ebola virus in vivo, enhancing viremia and pathogenesis. PLoS Negl. Trop. Dis. 2019, 13, e006983. [CrossRef]

224. Ichimura, T.; Mori, Y.; Aschauer, P.; Padmanabha Das, K.M.; Padera, R.F.; Weins, A.; Nasr, M.L.; Bonventre, J.V. KIM-1/TIM-1 is a Receptor for SARS-CoV-2 in Lung and Kidney. medRxiv 2020. [CrossRef]

225. Li, M.; Waheed, A.A.; Yu, J.; Zeng, C.; Chen, H.Y.; Zheng, Y.M.; Feizpour, A.; Reinhard, B.M.; Gummuluru, S.; Lin, S.; et al. TIM-mediated inhibition of HIV-1 release is antagonized by Nef but potentiated by SERINC proteins. Proc. Natl. Acad. Sci. USA 2019, 116, 5705-5714. [CrossRef]

226. Prasad, D.; Rothlin, C.V.; Burrola, P.; Burstyn-Cohen, T.; Lu, Q.; Garcia de Frutos, P.; Lemke, G. TAM receptor function in the retinal pigment epithelium. Mol. Cell Neurosci. 2006, 33, 96-108. [CrossRef] [PubMed]

227. Shimojima, M.; Takada, A.; Ebihara, H.; Neumann, G.; Fujioka, K.; Irimura, T.; Jones, S.; Feldmann, H.; Kawaoka, Y. Tyro3 family-mediated cell entry of Ebola and Marburg viruses. J. Virol. 2006, 80, 10109-10116. [CrossRef] [PubMed]

228. Lemke, G.; Burstyn-Cohen, T. TAM receptors and the clearance of apoptotic cells. Ann. N. Y. Acad. Sci. 2010, 1209, 23-29. [CrossRef] [PubMed]

229. Ma, W.; Li, S.; Ma, S.; Jia, L.; Zhang, F.; Zhang, Y.; Zhang, J.; Wong, G.; Zhang, S.; Lu, X.; et al. Zika Virus Causes Testis Damage and Leads to Male Infertility in Mice. Cell 2016, 167, 1511-1524.e1510. [CrossRef] [PubMed]

230. Nowakowski, T.J.; Pollen, A.A.; Di Lullo, E.; Sandoval-Espinosa, C.; Bershteyn, M.; Kriegstein, A.R. Expression Analysis Highlights AXL as a Candidate Zika Virus Entry Receptor in Neural Stem Cells. Cell Stem Cell 2016, 18, 591-596. [CrossRef] [PubMed]

231. Rothlin, C.V.; Carrera-Silva, E.A.; Bosurgi, L.; Ghosh, S. TAM receptor signaling in immune homeostasis. Annu. Rev. Immunol. 2015, 33, 355-391. [CrossRef] 
232. Liu, S.; DeLalio, L.J.; Isakson, B.E.; Wang, T.T. AXL-Mediated Productive Infection of Human Endothelial Cells by Zika Virus. Circ. Res. 2016, 119, 1183-1189. [CrossRef]

233. Retallack, H.; Di Lullo, E.; Arias, C.; Knopp, K.A.; Laurie, M.T.; Sandoval-Espinosa, C.; Mancia Leon, W.R.; Krencik, R.; Ullian, E.M.; Spatazza, J.; et al. Zika virus cell tropism in the developing human brain and inhibition by azithromycin. Proc. Natl. Acad. Sci. USA 2016, 113, 14408-14413. [CrossRef] [PubMed]

234. Savidis, G.; McDougall, W.M.; Meraner, P.; Perreira, J.M.; Portmann, J.M.; Trincucci, G.; John, S.P.; Aker, A.M.; Renzette, N.; Robbins, D.R.; et al. Identification of Zika Virus and Dengue Virus Dependency Factors using Functional Genomics. Cell Rep. 2016, 16, 232-246. [CrossRef] [PubMed]

235. Govero, J.; Esakky, P.; Scheaffer, S.M.; Fernandez, E.; Drury, A.; Platt, D.J.; Gorman, M.J.; Richner, J.M.; Caine, E.A.; Salazar, V.; et al. Zika virus infection damages the testes in mice. Nature 2016, 540, 438-442. [CrossRef]

236. Wells, M.F.; Salick, M.R.; Wiskow, O.; Ho, D.J.; Worringer, K.A.; Ihry, R.J.; Kommineni, S.; Bilican, B.; Klim, J.R.; Hill, E.J.; et al. Genetic Ablation of AXL Does Not Protect Human Neural Progenitor Cells and Cerebral Organoids from Zika Virus Infection. Cell Stem Cell 2016, 19, 703-708. [CrossRef]

237. Wang, S.; Qiu, Z.; Hou, Y.; Deng, X.; Xu, W.; Zheng, T.; Wu, P.; Xie, S.; Bian, W.; Zhang, C.; et al. AXL is a candidate receptor for SARS-CoV-2 that promotes infection of pulmonary and bronchial epithelial cells. Cell Res. 2021, 31, 126-140. [CrossRef]

238. Kato, H.; Takeuchi, O.; Sato, S.; Yoneyama, M.; Yamamoto, M.; Matsui, K.; Uematsu, S.; Jung, A.; Kawai, T.; Ishii, K.J.; et al. Differential roles of MDA5 and RIG-I helicases in the recognition of RNA viruses. Nature 2006, 441, 101-105. [CrossRef]

239. Lee, J.Y.; Bae, S.; Myoung, J. Middle East respiratory syndrome coronavirus-encoded ORF8b strongly antagonizes IFN- $\beta$ promoter activation: Its implication for vaccine design. J. Microbiol. 2019, 57, 803-811. [CrossRef]

240. Lee, J.Y.; Bae, S.; Myoung, J. Middle East Respiratory Syndrome Coronavirus-Encoded Accessory Proteins Impair MDA5-and TBK1-Mediated Activation of NF-кB. J. Microbiol. Biotechnol. 2019, 29, 1316-1323. [CrossRef]

241. Wichit, S.; Diop, F.; Hamel, R.; Talignani, L.; Ferraris, P.; Cornelie, S.; Liegeois, F.; Thomas, F.; Yssel, H.; Missé, D. Aedes Aegypti saliva enhances chikungunya virus replication in human skin fibroblasts via inhibition of the type I interferon signaling pathway. Infect. Genet. Evol 2017, 55, 68-70. [CrossRef]

242. Bae, S.; Lee, J.Y.; Myoung, J. Chikungunya Virus nsP2 Impairs MDA5/RIG-I-Mediated Induction of NF-кB Promoter Activation: A Potential Target for Virus-Specific Therapeutics. J. Microbiol. Biotechnol. 2020, 30, 1801-1809. [CrossRef]

243. Schilling, M.; Bridgeman, A.; Gray, N.; Hertzog, J.; Hublitz, P.; Kohl, A.; Rehwinkel, J. RIG-I Plays a Dominant Role in the Induction of Transcriptional Changes in Zika Virus-Infected Cells, which Protect from Virus-Induced Cell Death. Cells 2020, 9 , 1476. [CrossRef]

244. Riedl, W.; Acharya, D.; Lee, J.H.; Liu, G.; Serman, T.; Chiang, C.; Chan, Y.K.; Diamond, M.S.; Gack, M.U. Zika Virus NS3 Mimics a Cellular 14-3-3-Binding Motif to Antagonize RIG-I- and MDA5-Mediated Innate Immunity. Cell Host Microbe 2019, 26, 493-503.e496. [CrossRef]

245. Zeng, W.; Sun, L.; Jiang, X.; Chen, X.; Hou, F.; Adhikari, A.; Xu, M.; Chen, Z.J. Reconstitution of the RIG-I pathway reveals a signaling role of unanchored polyubiquitin chains in innate immunity. Cell 2010, 141, 315-330. [CrossRef]

246. Ramos, H.J.; Gale, M. RIG-I like receptors and their signaling crosstalk in the regulation of antiviral immunity. Curr. Opin. Virol. 2011, 1, 167-176. [CrossRef]

247. Schilte, C.; Couderc, T.; Chretien, F.; Sourisseau, M.; Gangneux, N.; Guivel-Benhassine, F.; Kraxner, A.; Tschopp, J.; Higgs, S.; Michault, A.; et al. Type I IFN controls chikungunya virus via its action on nonhematopoietic cells. J. Exp. Med. 2010, 207, 429-442. [CrossRef]

248. Lundberg, R.; Melén, K.; Westenius, V.; Jiang, M.; Österlund, P.; Khan, H.; Vapalahti, O.; Julkunen, I.; Kakkola, L. Zika Virus Non-Structural Protein NS5 Inhibits the RIG-I Pathway and Interferon Lambda 1 Promoter Activation by Targeting IKK Epsilon. Viruses 2019, 11, 1024. [CrossRef] [PubMed]

249. Hertzog, J.; Dias Junior, A.G.; Rigby, R.E.; Donald, C.L.; Mayer, A.; Sezgin, E.; Song, C.; Jin, B.; Hublitz, P.; Eggeling, C.; et al. Infection with a Brazilian isolate of Zika virus generates RIG-I stimulatory RNA and the viral NS5 protein blocks type I IFN induction and signaling. Eur. J. Immunol. 2018, 48, 1120-1136. [CrossRef]

250. Ortíz-López, F.J.; Monteiro, M.C.; González-Menéndez, V.; Tormo, J.R.; Genilloud, O.; Bills, G.F.; Vicente, F.; Zhang, C.; Roemer, T.; Singh, S.B.; et al. Cyclic colisporifungin and linear cavinafungins, antifungal lipopeptides isolated from Colispora cavincola. J. Nat. Prod. 2015, 78, 468-475. [CrossRef] [PubMed]

251. Estoppey, D.; Lee, C.M.; Janoschke, M.; Lee, B.H.; Wan, K.F.; Dong, H.; Mathys, P.; Filipuzzi, I.; Schuhmann, T.; Riedl, R.; et al. The Natural Product Cavinafungin Selectively Interferes with Zika and Dengue Virus Replication by Inhibition of the Host Signal Peptidase. Cell Rep. 2017, 19, 451-460. [CrossRef] [PubMed]

252. Müller, W.M.; Schmiederer, T.; Ensle, P.; Süssmuth, R.D. In vitro biosynthesis of the prepeptide of type-III lantibiotic labyrinthopeptin A2 including formation of a C-C bond as a post-translational modification. Angew. Chem. Int. Ed. Engl. 2010, 49, 2436-2440. [CrossRef]

253. Meindl, K.; Schmiederer, T.; Schneider, K.; Reicke, A.; Butz, D.; Keller, S.; Gühring, H.; Vértesy, L.; Wink, J.; Hoffmann, H.; et al. Labyrinthopeptins: A new class of carbacyclic lantibiotics. Angew. Chem. Int. Ed. Engl. 2010, 49, 1151-1154. [CrossRef] [PubMed]

254. Prochnow, H.; Rox, K.; Birudukota, N.V.S.; Weichert, L.; Hotop, S.K.; Klahn, P.; Mohr, K.; Franz, S.; Banda, D.H.; Blockus, S.; et al. Labyrinthopeptins Exert Broad-Spectrum Antiviral Activity through Lipid-Binding-Mediated Virolysis. J. Virol. 2020, 94. [CrossRef] 